\title{
Jak HPV wysokiego ryzyka indukuje optymalne środowisko dla własnej replikacji w różnicującym się nabłonku
}

How high-risk HPV induces an optimal environment for own replication in the differentiating epithelium

Aleksandra Kożańska², Katarzyna Baldy-Chudzik*1

${ }^{1}$ Katedra Mikrobiologii i Biologii Molekularnej, Instytut Nauk o Zdrowiu, Collegium Medicum, Uniwersytet Zielonogórsk

2 Instytut Nauk Biologicznych, Uniwersytet Zielonogórski

Abstrakt

Wirusy brodawczaka ludzkiego (HPV) są często czynnikami wywołującymi niegroźne dla człowieka infekcje, ale przetrwałe zakażenie niektórymi typami HPV jest poważnym zagrożeniem dla zdrowia, ponieważ jest związane z wieloma nowotworami, w tym z rakiem szyjki macicy oraz rosnącą liczbą nowotworów głowy i szyi. Cykl replikacyjny HPV jest ściśle zależny od różnicowania komórek wielowarstwowego nabłonka, co oznacza, że genom wirusa musi być replikowany za pomocą różnych mechanizmów na różnych etapach różnicowania komórek. Ustanowienie infekcji i utrzymywanie genomu wirusa zachodzi w proliferujących komórkach nabłonka, gdzie dostępność czynników replikacji jest optymalna dla wirusa. Jednak produktywna faza cyklu rozwojowego wirusa, w tym produktywna replikacja, późna ekspresja genów i wytwarzanie wirionów, zachodzi w wyniku różnicowania się nabłonka w komórkach, które prawidłowo opuszczają cykl komórkowy. Wirus wykorzystuje wiele szlaków sygnalizacyjnych komórki, w tym odpowiedź na uszkodzenia DNA (DDR, DNA damage response) do realizacji produktywnej replikacji własnego genomu. Zrozumienie mechanizmów związanych z cyklem replikacyjnym HPV jest potrzebne do ustalenia właściwego podejścia terapeutycznego do zwalczania chorób powodowanych przez HPV.

Słowa

kluczowe

papillomavirus $\cdot H P V \cdot$ replikacja wirusa • odpowiedź na uszkodzenia DNA

Otrzymano: 30.09.2020, Zaakceptowano: 25.05.2021

Abstract

Human papillomaviruses (HPV) are the most common causative agents of harmless human infections, but persistent infection with some types of HPV poses a serious health risk, because they are associated with many cancers, including cervical cancer and an increasing number of head and neck cancers. The replication cycle of HPV is closely dependent on the differentiation of the stratified mucosal epithelium, meaning that the viral genome must be replicated by different mechanisms at different stages of cell differentiation. The establishment of infection and the maintenance of the viral genome occur in proliferating epithelial cells, where the availability of replication factors is optimal for the virus. However, the productive phase of the viral life cycle, including productive replication, late gene expression and virion production, occurs as a result of epithelial differentiation in cells that normally exit the cell cycle. The virus uses a variety of cell signalling pathways, including DNA Damage Response (DDR), to perform productive replication of its own genome. Understanding the mechanisms involved in replication cycle of HPV is needed to establish an appropriate therapeutic approach to combat HPV related diseases.

Keywords

papillomavirus $\cdot H P V \cdot$ viral replication $\bullet$ DNA damage response

Received: 30.09.2020, Accepted: 25.05.2021

*Corresponding author e-mail: k.baldy-chudzik@cm.uz.zgora.pl

(B) Br-Nc-ND (C) 2021 Kożańska, Baldy-Chudzik, This work is licensed under the Creative Commons Attribution-NonCommercial-NoDerivs 4.0 License 


\section{Wstęp}

Wirusy brodawczaka ludzkiego (HPV, human papillomaviruses) to małe wirusy DNA, które infekują nabłonek skóry lub błon śluzowych w różnych miejscach anatomicznych człowieka, w tym drogi odbytowo-płciowe i jamę ustną [1]. Spośród ponad 220 zidentyfikowanych dotychczas typów HPV około 48 infekuje błonę śluzową lub skórę człowieka. Typy skórne najczęściej powodują brodawki, które rzadko są związane ze zmianą nowotworową [1, 2, 3]. Natomiast te, które wykazują tropizm do błon śluzowych człowieka, mają różne znaczenie kliniczne, a Międzynarodowa Agencja Badań nad Rakiem (IARC, International Agency for Research on Cancer) rekomenduje ich podział na trzy grupy:

- $\quad$ typy niskiego ryzyka (LR, low-risk, LR-HPV);

- $\quad$ typy prawdopodobnie wysokiego ryzyka (pHR, probably high-risk, pHR-HPV);

- $\quad$ typy wysokiego ryzyka (HR, high-risk, HR-HPV) (tab. 1) $[1,2,4]$.

Typy niskiego ryzyka powodują łagodne brodawki narządów płciowych i rzadko prowadzą do nowotworu. Do typów prawdopodobnie wysokiego ryzyka zalicza się te, dla których związek z onkogenezą nie został jednoznacznie potwierdzony. Grupa wysokiego ryzyka obejmuje onkogenne typy HPV, spośród których HPV16, 18, 31 i 45 są związane prawie z 99\% wszystkich raków macicy [2] i około $30 \%$ raka jamy ustnej i gardła (głównie HPV16) [6]. Szacuje się, że rak jamy ustnej i gardła związany z HPV wkrótce może przewyższyć raka szyjki macicy jako wiodący nowotwór związany z HPV [1, 7]. Wprawdzie tylko niewielka frakcja infekcji HPV przechodzi w zmianę nowotworową, to jednak przetrwałe infekcje HR-HPV są przyczyną 5\% wszystkich ludzkich nowotworów złośliwych.

Przetrwała infekcja typami wysokiego ryzyka jest uznana za czynnik niezbędny, ale też i niewystarczający do rozwoju raka. Wskazuje to, że oprócz infekcji HPV również czynniki interakcji wirus-gospodarz mogą się przyczyniać do wywołanego przez HPV procesu nowotworowego [7].
W zakażonej komórce białka wirusowe oddziałują z wieloma czynnikami gospodarza, które przyczyniają się do replikacji wirusa [1, 3]. Wiadomo też, że wirus rozwinął mechanizmy włączania szlaków naprawy DNA komórki gospodarza. Jednak sposób, w jaki te szlaki naprawcze są aktywowane, nie jest w pełni poznany [1].

Szczepionki skutecznie chronią przed początkową infekcją typami HR-HPV, ale nie działają terapeutycznie przeciwko istniejącym infekcjom [8]. Zwalczanie infekcji HRHPV opiera się nadal jedynie na zabiegach chirurgicznych i chemio/radioterapii [9]. Efektywny cykl replikacyjny HRHPV zależy od różnicowania nabłonka i aktywacji szlaków naprawy DNA gospodarza, które często odgrywają główną rolę $w$ rozwoju wielu nowotworów. Zrozumienie mechanizmów związanych z replikacją i cyklem rozwojowym HPV jest potrzebne do ustalenia właściwej terapii do zwalczania rozprzestrzeniania się HPV i chorób z nim związanych.

\section{Organizacja genomu HPV}

Wirusa HPV charakteryzuje ikosahedralny, bezosłonkowy kapsyd zbudowany z 72 kapsomerów złożonych z białek L1 i L2. Materiał genetyczny w postaci kolistej, dwuniciowej cząsteczki DNA składa się z około 8000 pz. Wewnątrz cząstki wirusa genom jest związany z histonami gospodarza, tworząc swoistą chromatynę $[1,10]$. W architekturze genomu występują wyraźnie wyróżnione trzy regiony:

- $\quad$ region wczesny, obejmujący siedem otwartych ramek odczytu (ORF, open reading frame): E1, E2, E4, E5, E6, E7 oraz E8;

- $\quad$ region późny, zawierający dwie ORF kodujące białka strukturalne kapsydu L1 i L2;

- $\quad$ region niekodujący określany jako długi region kontrolny LCR (Long Control Region) [1, 11] (ryc. 1). Niekodujący region (LCR) oddziela region wczesny od późnego i zawiera wirusowe miejsce startu replikacji (Ori), które obejmuje sekwencje wiążące białka E1 i cztery palindromowe sekwencje, wielkości 12 pz, docelowe dla

Tabela 1. Klasyfikacja ludzkich wirusów HPV na podstawie ich potencjału onkogennego, określanego jako prawdopodobieństwo wystąpienia transformacji nowotworowej w wyniku zakażenia [4. 5]

\begin{tabular}{|c|c|}
\hline Potencjał onkogenny & Typ wirusa HPV \\
\hline Typy nieonkogenne; niskiego ryzyka (LR-HPV) & $\begin{array}{c}2,6,7,11,13,27,28,29,32,40,44,57,61,62,72,74,77,81 \\
83,84,86,87,89,90,91,106\end{array}$ \\
\hline $\begin{array}{l}\text { Typy prawdopodobnie onkogenne; prawdopodobnie wysokiego ryzyka (pHR- } \\
\text { HPV) }\end{array}$ & $26,30,53,66,67,68,69,70,82,85$ \\
\hline Typy onkogenne; wysokiego ryzyka (HR -HPV) & $16,18,31,33,35,39,45,51,52,56,58,59$ \\
\hline
\end{tabular}


białka E2 [10, 12]. Trzy spośród nich otaczają bogate w A-T miejsce inicjacji replikacji $[12,13]$. LCR jest też miejscem wiązania wielu czynników transkrypcyjnych oraz regulatorowych gospodarza, które albo aktywują, albo tłumią wczesne (E) i późne (L) promotory genów wirusowych (PE: P97 - HPV16, P105 - HPV18; PL: P670 - HPV16, P811 - HPV18). Promotor wczesny znajduje się w końcowym odcinku regionu LCR (P97 u HPV16) i odpowiada za transkrypcję ORFs regionu wczesnego. Promotor późny jest usytuowany w obrębie ORF E7 (P970 u HPV16) i podlega aktywacji w końcowym etapie cyklu replikacyjnego wirusa, umożliwiając ekspresję białek późnych i tworzenie potomnych wirionów. Wirusowe mRNA ulega poliadenylacji w jednym $z$ dwóch miejsc - wczesnym (pAE) bądź późnym (pAL) w zależności od tego, który promotor jest miejscem inicjacji transkrypcji. Geny są transkrybowane z jednej nici DNA jako policistronowe jednostki transkrypcyjne, które są alternatywnie składane w celu uzyskania produktów poszczególnych genów [10, 14].

Wczesne białka są niestrukturalne i uczestniczą w różnych funkcjach regulatorowych. Białko E1 jest helikazą zależną od ATP, która również rekrutuje komórkowe czynniki

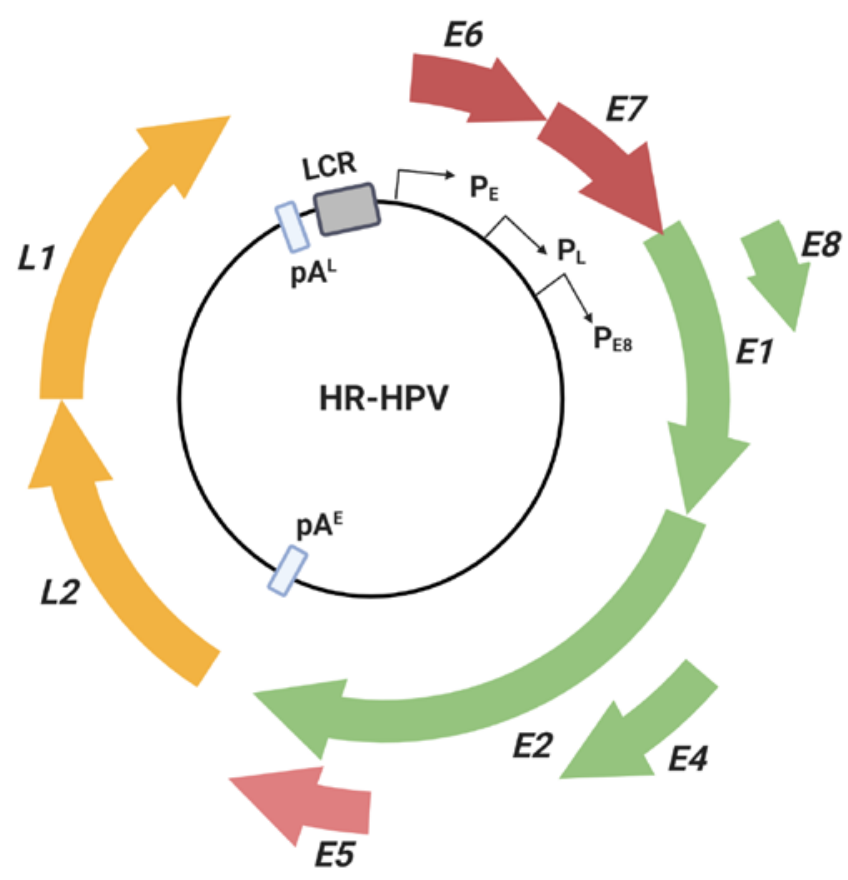

Rycina 1. Organizacja genomu typowa dla HPV wysokiego ryzyka. E1, E2, E4, E5, E6, E7, E8 - geny wczesne; L1, L2 - geny późne; LCR - długi region kontrolny zawierający miejsce startu replikacji; $\mathrm{P}_{\mathrm{E}}, \mathrm{P}_{\mathrm{E} 8}$ - promotory wczesne, $\mathrm{P}_{\mathrm{L}}$ - promotor późny; $p A^{\mathrm{E}}-$ miejsce poliadenylacji wczesne, $\mathrm{pA}^{\mathrm{L}}$ - miejsce poliadenylacji późne replikacji DNA do wirusowego miejsca startu replikacji [13]. Białko E2 współdziała z E1 w celu ułatwienia inicjacji replikacji genomu wirusa, a także reguluje ekspresję genów wirusowych od wczesnego promotora i odgrywa rolę w rozdzielaniu genomów wirusa do komórek potomnych [15]. E6 i E7 są onkoproteinami dla typów HR-HPV i pełnią wiele różnych funkcji, takich jak: manipulacja cyklem komórkowym, hamowanie apoptozy czy też unikanie odpowiedzi immunologicznej gospodarza [16, 17]. E4 usprawnia replikację wirusowego DNA i ułatwia uwalnianie wirionów [18]. Białko E5 zapobiega apoptozie, a także wykazuje aktywność stymulującą proliferację i może brać udział w transformacji komórek [19]. L1 i L2 są późnymi białkami strukturalnymi, które tworzą kapsyd wirusowy. Białko E8^E2 (krótsza forma E2) jest kodowane przez składany alternatywnie transkrypt i moduluje zarówno replikację jak i transkrypcję wirusa. Wykazano, że jest niezbędne do utrzymania trwałej, nieproduktywnej fazy infekcji i prawdopodobnie infekcji latentnej [20].

\section{Cykl rozwojowy HPV}

Cykl rozwojowy HPV jest ściśle zależny od różnicowania komórek wielowarstwowego nabłonka. HR-HPV i LRHPV inicjują infekcję, uzyskując dostęp do proliferujących komórek podstawnych nabłonka w wyniku urazu [5]. W początkowym przyłączeniu HPV do komórek uczestniczy białko kapsydowe L1, które wiąże się z receptorem pierwotnym, proteoglikanem siarczanu heparanu (HSPG, Heparan Sulfate ProteoGlycan), na powierzchni komórki warstwy podstawnej nabłonka lub na błonie podstawnej [3]. Związanie HSPG zmienia konformacyjnie strukturę kapsydu i stopniowo proteolitycznie rozszczepia białka L1 i L2, a to umożliwia wiązanie $z$ wtórnym receptorem wychwytującym na powierzchni błony plazmatycznej komórki docelowej. HPV dostaje się do komórek w procesie endocytozy i w pęcherzyku transportowym zachodzi oddzielenie białek L1 od L2 [3]. Genom wirusa pozostaje w kompleksie z białkiem L2 i w tej postaci przemieszcza się do sieci trans-Golgiego [21]. Białko L2 jest też wymagane do efektywnego przemieszczenia genomu wirusowego do jądra komórki [22]. Dostarczenie kompleksu L2/DNA HPV do jądra wymaga progresu cyklu komórkowego do wczesnej mitozy i dezintegracji błony jądrowej [23]. Wewnątrz jądra, L2 pośredniczy w kotwiczeniu genomu wirusa do domeny jądrowej 10 (ND10, nuclear domain 10), zwanej również ciałem białaczki promielocytowej (PML, promyelocytic leukaemia). Takie umiejscowienie jądrowe jest powszechnie wykorzystywane przez wirusy DNA do inicjacji transkrypcji [24]. Jednak w przeciwieństwie do wielu wirusów DNA, 
które zaburzają strukturę PML po infekcji jądrowej, HPV prawdopodobnie wymaga integralności PML do ustalenia infekcji jądrowej i wczesnej replikacji [1, 24].

HPV nie ma własnej polimerazy DNA i replikacja jego genomu jest zależna od komórkowych czynników replikacji i transkrypcji. Wirusowy cykl rozwojowy obejmuje trzy fazy replikacji:

- $\quad$ wczesną fazę infekcji w niezróżnicowanych, dzielących się komórkach,

- utrzymywanie infekcji w komórkach podlegających różnicowaniu oraz

- amplifikację produktywną w komórkach zróżnicowanych [25] (ryc. 2).

Wczesna faza infekcji polega na utrzymaniu stałej liczby kopii episomalnych genomów HPV (około 50-100 kopii) w zakażonych komórkach. Po wniknięciu DNA wirusa do jądra komórkowego rozpoczyna się wczesna transkrypcja genów wirusa [26]. Wczesna ekspresja białka E2, jako wirusowego czynnika transkrypcyjnego, umożliwia uruchomienie $z$ wirusowego wczesnego promotora ekspresji białek regulatorowych E6 i E7. Te onkogenne białka są ukierunkowane na inhibicję i degradację kluczowych supresorów nowotworu - p53 i pRb, prowadząc do promowania proliferacji komórkowej [26]. E2 pełni też funkcję czynnika inicjacji replikacji wirusa [27]. W LCR E2 działa jako moduł montujący i stabilizujący helikazę E1, aby ułatwić wiązanie E1 z miejscem startu replikacji [12]. Helikaza E1 wiąże i rozwija DNA, aby umożliwić dostęp komórkowym czynnikom replikacji do wirusowego DNA [25, 27]. Replikacyjne białka wirusa oddziałują z wieloma czynnikami gospodarza, w tym z polimerazą DNA, topoizomerazą 1 i replikacyjnym białkiem A wiążącym jednoniciowe DNA (RPA, replication protein A). Pierwsza faza replikacji genomu HPV jest najważniejsza do zainicjowania trwałej infekcji $[25,27]$. W zakażonych komórkach podstawnych episomalne genomy wirusowe są replikowane wspólnie z replikacją komórkowego DNA i równo rozdzielane do komórek potomnych dzięki kotwiczeniu genomów wirusa do chromosomów gospodarza przez E2 związane z wirusowym LCR i białkami wiążącymi chromatynę [20, 25]. Wykazano, że ograniczona amplifikacja genomu wirusowego jest kontrolowana przez białko E8^E2 (krótsza forma E2) za pośrednictwem komórkowego kompleksu NCoR/SMRT (nuclear receptor corepressor/silencing mediator of retinoic acid and thyroid hormone receptor) [20]. W zakażonych komórkach podstawnych białka wirusowe ulegają ekspresji na niskim poziomie, aby uniknąć aktywacji miejscowej odpowiedzi odpornościowej [28]. Wirus osiąga to przez represje transkrypcji E2 z wczesnego promotora (P97 u HPV16) w wyniku zahamowania dostępu czynnikom

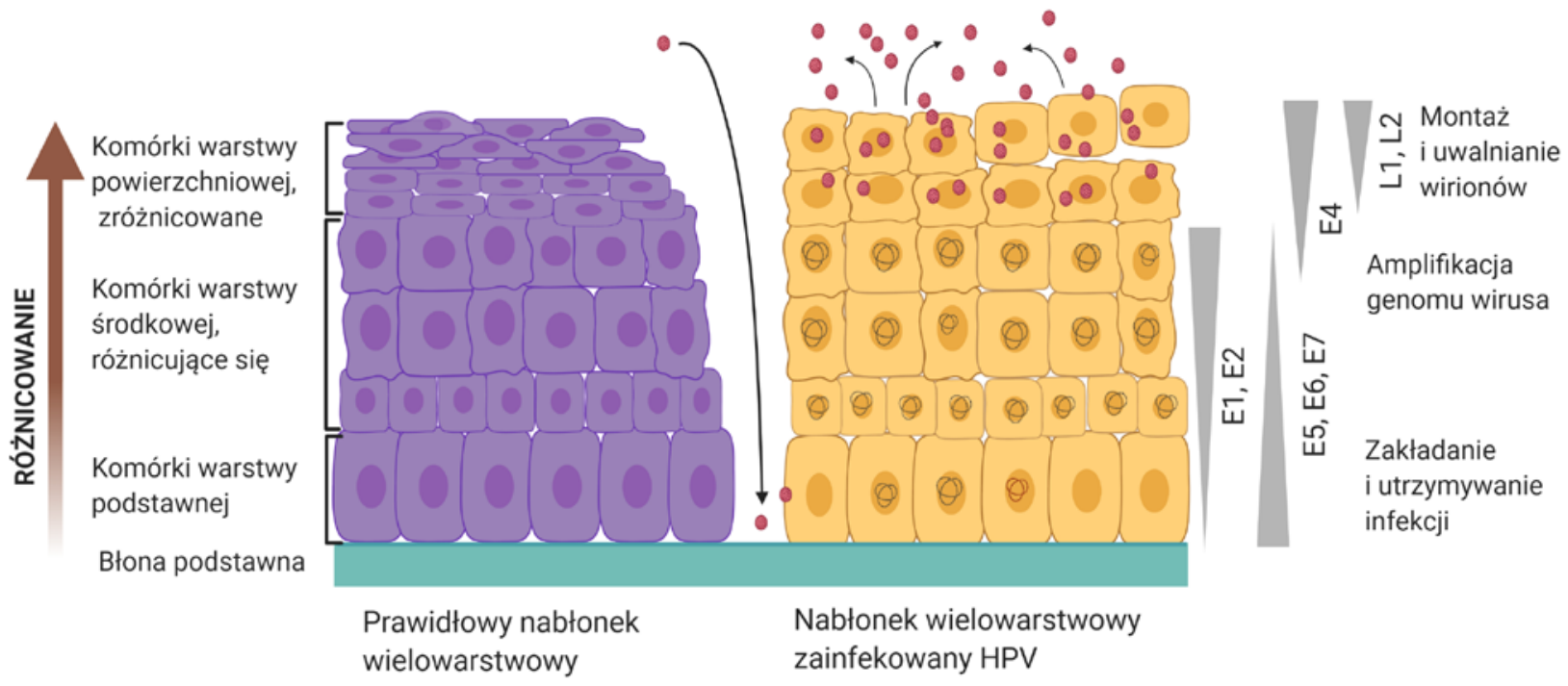

Rycina 2. Cykl życiowy wirusa HPV. HPV infekuje komórki podstawne wielowarstwowego nabłonka poprzez uraz. Nabłonek zakażony wirusem HPV przedstawiono po prawej stronie, a niezainfekowany nabłonek po lewej stronie. Po zakażeniu HPV przechodzi replikację do poziomu 50100 episomów/komórkę. W fazie zakładania i utrzymywania infekcji zachodzi ekspresja genów wczesnych (E1, E2, E4, E5, E6, E7). Genomy wirusów sa stabilnie utrzymywane $w$ warstwie podstawnej nabłonka poprzez replikację w fazie $S$ wraz $z$ komórkowym DNA. Po podziale komórki jedna komórka potomna migruje z warstwy podstawnej i zaczyna się różnicować. Różnicowanie uruchamia produktywną fazę cyklu życiowego wirusa, co wywołuje ekspresję genów późnych i amplifikację genomu wirusa. Ciągła ekspresja E6 i E7 dereguluje kontrolę cyklu komórkowego, wypychając komórki różnicujące się, po mitozie, z powrotem do fazy G i zapewniając produktywną replikację wirusa. Ekspresja L1 i L2 w najwyższych warstwach nabłonka prowadzi do montażu i uwolnienia zakaźnych wirionów podczas złuszczania nabłonka 
transkrypcyjnym do promotora i przez zmianę konformacji chromatyny [29].

Podział zakażonej komórki podstawnej nabłonka może wytwarzać komórkę, która jest zdolna do różnicowania. Komórki te, przemieszczając się do górnych warstw, niosą ze sobą wirusowe genomy. Ten etap cyklu rozwoju wirusa to faza utrzymywania infekcji, liczba kopii genomu wirusa pozostaje na poziomie 50-100 na komórkę [5].

O ile czynniki replikacji są łatwo dostępne do stabilnego utrzymania episomów wirusa w niezróżnicowanych komórkach, to różnicowanie nabłonka zwykle powoduje wyjście komórek z cyklu komórkowego, ograniczając wirusowi dostęp do czynników replikacji w komórkach postmitotycznych [5]. HPV wykorzystuje liczne mechanizmy do obalenia głównych ścieżek regulacyjnych, które kierują replikacją komórkową, i wykształcił strategię zapobiegania zatrzymaniu cyklu komórkowego i sygnałom apoptozy. Działanie białek wirusowych zmusza różnicujące się komórki do ponownego wejścia w cykl komórkowy i przejścia do fazy G2, podczas której genomy HPV są replikowane do tysięcy kopii na komórkę w procesie nazywanym fazą amplifikacji produktywnej cyklu replikacyjnego wirusa [5, 30]. Podczas replikacji produktywnej onkoproteiny E6 i E7 odgrywają ważną rolę, utrzymując inaktywację p53, pRb, a to zapewnia zróżnicowanym komórkom aktywne trwanie w cyklu komórkowym i zapobiega apoptozie. Wydajna replikacja wirusowego DNA, w fazie amplifikacji, wymaga wysokiego poziomu białek E1 i E2, które ulegają ekspresji w wyniku aktywacji późnego promotora. Białka E4 i E5 przyczyniają się do wydajnej produktywnej replikacji $[18,19]$. Białka L1 i L2 ulegają ekspresji z mRNA, które są inicjowane z późnego promotora w zróżnicowanych keratynocytach warstwy powierzchniowej [5].

Wykazano, że w przypadku HR-HPV (HPV16 i 31) ekspresja białek kapsydu jest opóźniana do czasu, aż zainfekowane komórki nie dotrą do warstwy powierzchniowej nabłonka. Takie opóźnienie i ograniczenie ekspresji immunogennych białek kapsydu do najwyższej warstwy nabłonka, pozwala wirusowi uniknąć odpowiedzi immunologicznej gospodarza [31]. Zrozumienie związku między różnicowaniem komórkowym a ekspresją białek kapsydu może wspomóc zaprojektowanie takiego leku przeciwwirusowego, który zakłóci opóźnioną ekspresję L1 i L2, doprowadzając do jej indukcji w dolnych warstwach nabłonkowych, a to umożliwiłoby aktywację silnej przeciwwirusowej odpowiedzi immunologicznej.

\section{Rola białek E4 i E5 w cyklu rozwojowym wirusa}

Białka E4 (określane też jako E1^E4) HPV16 i 18 mogą regulować aktywności białka E2, co sugeruje możliwość centralnego regulowania zależności między replikacją i transkrypcją wirusów. Badania z wykorzystaniem organotypowych modeli nabłonka potwierdziły, że E4 może się bezpośrednio przyczyniać do amplifikacji genomu wirusa w produktywnej fazie cyklu replikacji przez stabilne utrzymywanie cyklu komórkowego w fazie G2 [18, 32] i aktywację kinaz komórkowych z rodziny MAPK (MitogenActivated Protein Kinases; ERKs, JNK/SAPKs i p38 MAPKs) [33]. Ponadto zdolność E4 do zatrzymywania komórek w fazie G2 może przeciwdziałać działaniu, jakie wywiera białko E7, stymulując przejście z fazy G1 do fazy $S[32,33]$. E4 HPV16 wykazuje zdolność do wiązania helikazy RNA DEAD box, która może się przyczyniać do potranskrypcyjnej kontroli ekspresji genów wirusowych [33, 34]. Ważną rolą E4 jest restrukturyzacja filamentów cytokeratyny, aby ułatwić uwalnianie nowych wirionów ze złuszczanych komórek nabłonka [18, 34].

E5 jest transbłonowym białkiem rezydującym w retikulum endoplazmatycznym (ER) [19], które może stabilizować receptor naskórkowego czynnika wzrostu (EGFR, Epidermal Growth Factor Receptor) i stymulować aktywność MAPK, co sugeruje, że może kontrolować podział komórek [19]. To, że genomy HPV zawierające inaktywujące mutacje w ORF E5 mają niższy poziom amplifikacji genomu wirusowego niż typ dziki, może być związane z interakcją E5 z sygnalizacją komórkową i możliwością regulowania apoptozy [19]. Ponadto E5 pomaga wirusowi unikać odpowiedzi immunologicznej przez represję prezentacji wirusowych peptydów w związku z MHC (major histocompatibility complex) [35]. Wykazano też, że E5 HPV16 jest zdolne do tworzenia wiroporyny, która prawdopodobnie wykazuje aktywność kanału jonowego w zakażonych komórkach, co może się wiązać ze wzmocnieniem aktywności EGFR przez E5 [36].

\section{Aktywności białek HPV E6 i E7 podczas cyklu replikacji wirusa}

HPV do realizacji cyklu replikacji wymaga dostępu do komórkowych czynników replikacji DNA, co wiąże się z akumulacją czynników gospodarza zaangażowanych w zatrzymanie cyklu komórkowego i apoptozę. Wirus blokuje sygnały przeciwproliferacyjne przez skoordynowane działania onkoprotein E6 i E7, aby zapewnić zakażonym komórkom trwanie w aktywnym cyklu komórkowym i replikację własnego DNA. W zakażonych komórkach białko E7 zawsze występuje razem z białkiem E6 z powodu bicistronowej natury regionu kodującego E6 i E7 w genomie HPV [28, 37]. Badania wykazały podwyższony poziom mRNA kodującego białka E6 i E7 w niezróżnicowanej i różnicującej się warstwie nabłonka oraz obniżoną 
ekspresję w zróżnicowanych warstwach [38]. Sugeruje to, że aktywność E6 i E7 może być najważniejsza we wczesnej fazie replikacji wirusa w podstawnych komórkach nabłonka, aby utrzymać zdolności proliferacyjne komórek i zapobiegać apoptozie [39, 40].

Białko E7, w różnicujących się komórkach HPVdodatnich, aktywuje ponowne wejście w cykl komórkowy przez wiązanie, inaktywację i degradację białek należących do rodziny siatkówczaka (RB, retinoblastoma). Rb wraz z p107 i p130 kontrolują przełączanie między fazami G1 i $S$ cyklu komórkowego, regulując aktywność czynników transkrypcyjnych E2F [41]. Rodzina białek E2F kontroluje transkrypcję genów zaangażowanych $w$ replikację fazy $\mathrm{S}$, postęp cyklu komórkowego, różnicowanie, naprawę uszkodzeń DNA, proliferację i apoptozę. Rb, tworząc kompleks $\mathrm{z}$ E2F, tłumi transkrypcje $\mathrm{z}$ promotorów zależnych od E2F. Podczas zakażeń HR-HPV, E7 wiąże $\mathrm{Rb}$ i ukierunkowuje jego degradację przez szlak ubikwityny proteasomalnej. Prowadzi to do konstytutywnej ekspresji genów reagujących na E2F, w tym genów wymaganych do syntezy nukleotydów (reduktaza dihydrofolianowa i kinaza tymidynowa), replikacji DNA (polimeraza DNA i cdc6) oraz postępu cyklu komórkowego (cyklina A i E, cdc2 i c-Myc) i umożliwia syntezę wirusowego DNA [41]. Aktywność białka E7 rozszerza w ten sposób przedział komórek nabłonkowych aktywnych w replikacji DNA [42]. E7 może także oddziaływać bezpośrednio z czynnikiem transkrypcji E2F, co stymuluje aktywność promotorów genów kontrolujących wzrost [41]. Wykazano też wiele możliwych stymulujących i hamujących aktywności E7 na inne komórkowe czynniki transkrypcyjne, takie jak STAT1, NF-kB, IRF1, SMAD2/3, TBP, Miz 1, B-Myb, c-Myc, c-Jun, c-Fos, E2F1 i E2F6 [39, 41]. Obserwacje te wskazują na istotny potencjał E7 do dokonywania znaczących zmian transkrypcyjnych w zainfekowanych komórkach.

Niezakażone komórki reagują na każde nieplanowane zdarzenie proliferacji indukowaniem apoptozy. Jednym z następstw indukowanej przez E7 degradacji Rb jest wzrost poziomu supresora nowotworu i głównego regulatora apoptozy, białka p53 [42]. Aby zapobiec aktywowaniu apoptozy w komórkach replikujących HR-HPV, wirusowe białka E6 wiążą p53 i rekrutują komórkowe białko E3 związane z ligazą ubikwityny E6 (E6-AP, E6 associated protein) do jego ubikwitynacji i proteasomowej degradacji [43]. E6 HR-HPV hamują również funkcję p53 przez wiązanie acetylotransferaz histonowych, p300 i CBP (białko wiążące CREB, CREB-binding protein), które sa koaktywatorami aktywności p53 [10]. Powodują też zmianę konformacji p53 i jego sekwestrację w cytoplazmie [44]. Interakcje te destabilizują p53, umożliwiając komórkom kontynuowanie cyklu komórkowego w celu replikacji wirusa. Ponieważ p53 jest głównym regulatorem zarówno postępu cyklu komórkowego jak i reakcji na stres środowiskowy, jego inaktywacja przez E6 sprzyja również niestabilności genomu zakażonych komórek i zwiększa ryzyko raka [44, 45].

Dodatkowe elementy mechanizmów apoptotycznych gospodarza, z którymi wiąże się E6, obejmują białko Bak, receptor czynnika martwicy nowotworów 1 (TNF R1, tumor necrosis factor receptor 1), adaptorową cząsteczkę domeny śmierci Fas (FADD, Fas-associated protein with death domain) i kaspazę 8 [45, 46]. Wykazano też, że E6 HPV16 wywołuje proteasomalną degradację tuberiny i wiąże się z paksyliną, białkiem, które odgrywa istotną rolę w strukturalnej organizacji komórki [46, 47, 48].

Białka E6 są zdolne do oddziaływania i degradacji białek zawierających domeny PDZ (PSD95/hDlg/ZO-1), które kontrolują sygnalizację komórkową, kształt i biegunowość komórki. Białka E6 HR-HPV zawierają C-końcową domenę PBM (PDZ domain binding motif) umożliwiającą wiązanie z białkami PDZ. Wykazano, że obecność motywu PBM w cząsteczce E6 jest wymagana zarówno do utrzymywania formy episomalnej genomu jak i amplifikacji HR-HPV. Motyw PBM może być również wymagany do aktywacji cyklu komórkowego w zakażonych HPV komórkach i hamowania apoptozy przez NF-kB (nuclear factor-kappa B) [40, 47, 49]. PBM E6 umożliwia także regulacyjną interakcję z sortazą SNX27 (nexina 27, sorting nexin family member 27), która kontroluje transport endosomalny, pozyskiwanie składników odżywczych i proliferację komórek [46]. Wykazano, że E6 HPV16 wiąże się z IRF-3 (czynnik regulacyjny 3 interferonu (IFN), interferon regulatory factor 3) i znosi aktywność transkrypcyjną promotora IFN- $\beta$ [48]. E6 zakłóca również szlak sygnalizacji z udziałem IFN- $\alpha$, doprowadzając do zahamowania aktywacji genów reagujących na IFN [44].

HPV16 E6 i E7 zapobiegają też ekspresji TLR9 (receptor podobny do Toll 9, Toll like receptor 9), który rozpoznaje dwuniciowe DNA (dsDNA, double stranded DNA) w zainfekowanej komórce w celu aktywacji wrodzonej odpowiedzi immunologicznej. Ponadto zarówno E6, jak i E7 hamują cytokiny, takie jak TNF- $\alpha$ (czynnik martwicy nowotworu $\alpha$, tumor necrosis factor $\alpha$ ), TGF- $\beta$ (transformujący czynnik wzrostu $\beta$, transforming growth factor $\beta$ ) i IFN, zmieniając sygnalizację cytokin i wrodzoną odporność. E6 HR-HPV hamuje IFN-k przez metylację DNA, aby znieść odpowiedź komórkową na infekcję wirusową. Ponadto E6 kontroluje IL1- $\beta$ (interleukina-1 beta, interleukin 1 beta) poprzez E6-AP i degradację za pośrednictwem p53 [46, 47, 48, 49].

Oprócz wspomnianych wyżej białek E6 istnieją też inne izoformy tego białka, które wykryto w próbkach od pacjentów HPV-dodatnich. Region genu E6E7 genomu HPV16 powoduje powstanie co najmniej czterech alternatywnie składanych form mRNA (E6 pełnej długości (E6fl), E6*I, E6*II, E6*III [zwany także E6*X]) [50]. Białka kodowane 
przez izoformy E6 nie zostały jeszcze dostatecznie zbadane, ale mogą być ważne zarówno dla cyklu replikacji wirusa, jak i postępu rozwoju nowotworów związanych z HPV [51].

Oddziaływanie białek wirusowych między sobą

Wyjaśnienie roli różnych białek wirusowych w replikacji wirusa jest dość złożone i wynika z kilku przyczyn, takich jak:

- wielofunkcyjność białek,

- $\quad$ zdolność do wiązania się części białek wirusowych ze sobą,

- zmiany w profilach ekspresji tych białek podczas różnicowania nabłonka i

- kompartmentalizacja subkomórkowa.

Jak już omówiono, E1 i E2 oddziałują z wirusowym miejscem startu replikacji, aby zainicjować replikację wirusa [12]. Jednak wykazano również, że E2 jest wiązane przez L1, L2, E6, E6*I, E7 i E4. Wiązanie E2 z L2 do domen ND10 w jądrach zainfekowanych komórek wydaje się odgrywać rolę $w$ fazie ustanawiania infekcji w podstawnych komórkach nabłonka [52]. Ponadto L2 może hamować transaktywację transkrypcyjną E2, ale nie replikację wirusowego DNA indukowaną przez E2 [53]. Zatem L2 może działać jako sensor przełączania między aktywacją wczesnej transkrypcji wirusowej a ograniczoną replikacją genomu wirusowego w fazie ustanawiania infekcji. E2 może rekrutować E7 do mitotycznych chromosomów w późnej mitozie. Sugerowano, że oligomery E2-E7 mogą spowodować zniesienie represji wywoływanej przez E2 na ekspresję E6 i E7, aby przyczynić się do progresji nowotworu związanego z HR-HPV [54]. Oddziaływanie między izoformami E2 i E6 zmienia wewnątrzjądrowe umiejscowienie białek, a to może zmieniać ich funkcje komórkowe [55]. Podobnie E2 po związaniu z E4 ulega relokacji i stabilizacji cytoplazmatycznej [32], ale rola E2 w cytoplazmie nie została jeszcze zbadana. E2 i L1 łączą się w ciałkach jądrowych PML podczas składania wirionów [53]. Nie można wykluczyć, że współpracujące kompleksy białek wirusowych mogą pełnić dodatkowe, niepoznane jeszcze funkcje.

\section{Małe niekodujące RNA a cykl replikacyjny HPV}

Stale wzrasta zainteresowanie rolą małych niekodujących RNA (mikro-RNA) w zakażeniach HPV. Mikro-RNA (miRNA) - to cząsteczki wielkości 22-25 nukleotydów, które kontrolują ekspresję wielu genów docelowych na poziomie potranskrypcyjnym, wpływając na stabilność i translację mRNA [56].
Zidentyfikowano i zwalidowano kilka miRNA kodowanych przez HR-HPV [57, 58]. Jednak z powodu ich niskiej ekspresji, zarówno w kulturach organotypowych jak i w różnych próbkach klinicznych HPV-dodatnich, ich charakterystyka jest niepełna. Sugeruje się, że mogą mieć znaczenie w ustalaniu latencji wirusa i unikaniu odporności $[59,60]$.

Wiadomo jednak, że infekcja HR-HPV prowadzi do dużych zmian i zróżnicowanej ekspresji szerokiego zakresu komórkowych miRNA w porównaniu do komórek niezainfekowanych. W komórkach HR-HPV dodatnich, miRNA są regulowane przez białka E6 i E7, przez ich wpływ na poziomy białek p53 i pRB. W związku z tym powszechnie przyjmuje się pogląd, że w infekcji HPV wszystkie miRNA regulowane przez czynniki sygnalizacyjne szlaków p53 i pRB sa modulowane przez te onkoproteiny [61]. Jednoznacznie potwierdzono, że białko E6 kontroluje ekspresję komórkowych miRNA, takich jak: miR-23b, miR-218 i miR34a. Wykazano, że miR-34 jest kontrolowany przez p53, a jego degradacja za pośrednictwem E6 zahamowuje ekspresję genów związanych z apoptozą [62]. Stwierdzono też, że miR-203 pozostaje pod kontrolą negatywną białka E7 podczas amplifikacji genomu wirusa. miR-203 kontroluje ekspresję czynnika transkrypcyjnego Np63, którego poziom wzrasta w wyniku zahamowania aktywności miR-203 przez E7, co wydłuża aktywny cykl komórkowy w różnicujących się keratynocytach [63]. Wykazano też, że oddziaływanie białek E7 z E2F zwiększa poziomy ekspresji miR-15a i miR-16-1 [64]. W rzeczywistości E6 i E7 kontrolują wiele komórkowych czynników transkrypcyjnych, przez co mają wiele możliwości zmian ekspresji licznych miRNA transkrybowanych przez polimerazę II, w tym także takich, które mogą być zaangażowane w cykl replikacji wirusów. Przykładem są badania Wang i wsp., którzy wykorzystując analizę mikromacierzy i sekwencjonowanie (miRNA seq) dokonali analizy profilu miRNA odpowiadających na obecność białek E6 i E7 HPV31 w organotypowych hodowlach keratynocytów. Uzyskane wyniki ujawniły wzrost poziomu ekspresji dla miR16, miR-25, miR-92a, miR-93, miR-106b, miR-210, miR224, miR-378 i miR-22, miR-24, miR-27a, miR-29 i miR100 w porównaniu z niezainfekowaną kulturą [65]. Badania Honegger i wsp. ujawniły znaczny wzrost ekspresji miR143-3p, miR-23a-3p, miR-23b-3p, miR-27b-3p oraz znaczny spadek ekspresji miR-17-5p, miR-186-5p, miR-378a-3p, miR- 378, miR-629-5p i miR-7-5p po wyciszeniu genu E6/ E7 w komórkach HeLa i SiHa, co było skorelowane ze wzrostem komórek i hamowaniem apoptozy [66]. Zaznaczyć warto, że wirus może modulować ekspresję komórkowych miRNA w celu kontrolowania swojego cyklu replikacyjnego. $\mathrm{Na}$ przykład miR-145 oddziałuje z określonymi regionami sekwencji genów E1 i E2 HPV31 i jego nadekspresja wpływa na utrzymywanie ograniczonej liczby kopii genomu 
wirusa we wczesnej fazie cyklu replikacyjnego wirusa [67]. Profil miRNA jest uważany za swoisty odcisk palca stanu komórkowego. Możliwość ustalenia odpowiednich algorytmów profili miRNA w chorobach związanych z HPV stanowi obiecujące narzędzie o dużych możliwościach w diagnostyce i medycynie spersonalizowanej.

\section{Odpowiedź komórki gospodarza na uszkodzenie DNA a amplifikacja genomu HPV}

\section{Odpowiedź komórki gospodarza na uszkodzenie DNA}

Integralność genomu eukariotycznego jest utrzymywana za pośrednictwem złożonego systemu sygnalizacji i aktywacji o wspólnej nazwie - odpowiedź na uszkodzenie DNA (DDR, DNA damage response). DDR wykrywa uszkodzenia

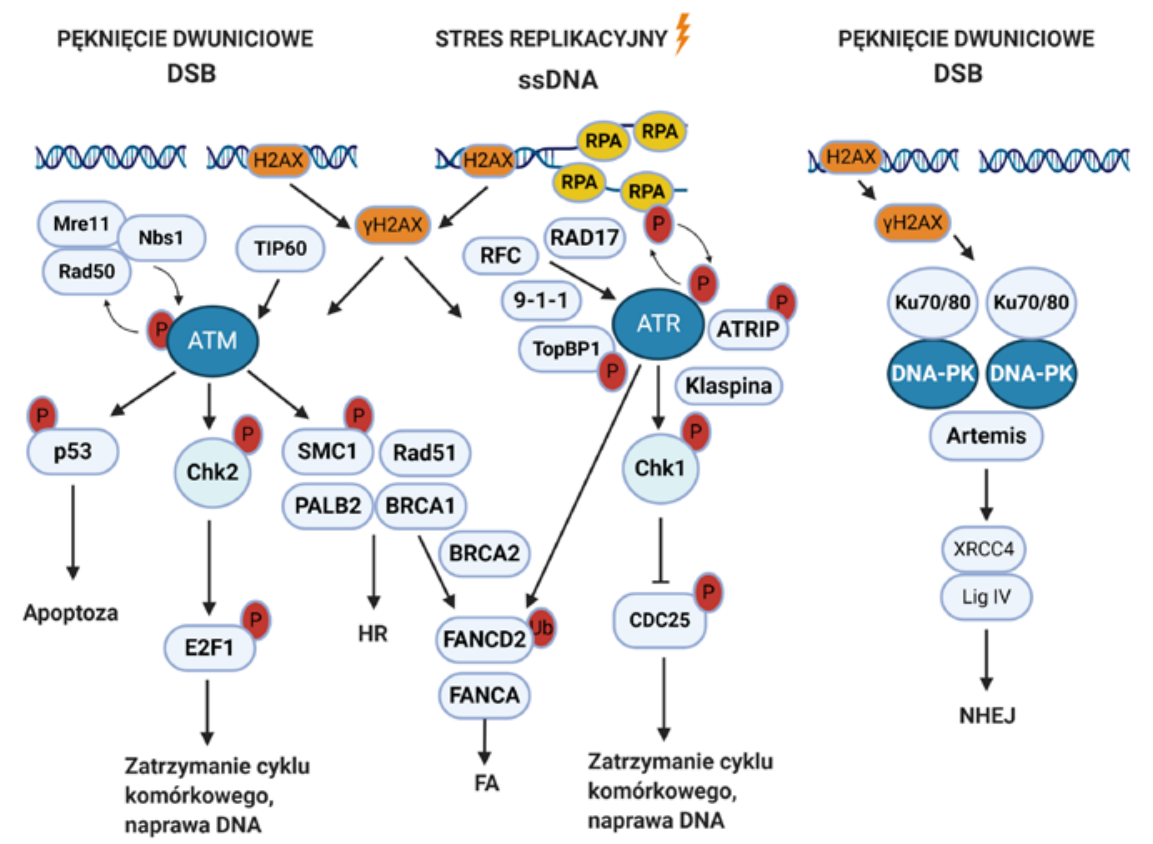

DNA, zatrzymuje cykl komórkowy i aktywuje mechanizmy naprawcze lub eliminuje uszkodzone komórki poprzez apoptozę. W komórce uszkodzenia DNA są wykrywane za pomocą wyspecjalizowanych sensorów. Sygnały uszkodzenia DNA są przekazywane do cząsteczek efektorowych z wykorzystaniem szlaków transdukcji sygnału, opartych na modyfikacji potranslacyjnej, jaką jest głównie fosforylacja [68]. Głównymi kinazami, które koordynują odpowiedź na uszkodzenie DNA, są: zmutowana ataksja teleangiektazja (ATM, ataxia telangiectasia mutated) i ataksja teleangiektazja związana z białkiem Rad3 (ATR, ataxia telangiectasia and Rad3-related protein). Są to serynowo/treoninowe kinazy z nadrodziny białek związanych z kinazą 3-fosfatydyloinozytolu (PIKK, phosphatidylinositol 3-kinase-related kinase) [69]. Razem z zależną od DNA kinazą białkową (DNA-PK, DNA-dependent protein kinase), ATM i ATR regulują najszerszy zakres czynników/efektorów

Rycina 3. Szlaki odpowiedzi na uszkodzenia DNA komórki. Szlaki ATM i ATR są aktywowane w odpowiedzi na sygnały uszkodzenia DNA, co prowadzi do zatrzymania punktu kontrolnego cyklu komórkowego, naprawy DNA lub apoptozy. ATM jest aktywowana przez pęknięcia podwójnej nici DNA (DSB) i inicjuje kaskadę odpowiedzi przez fosforylację białek efektorowych, w tym kinaza Chk2 i białek naprawy DNA - BRCA1 i pSMC1. Oprócz naprawy DSB, ATM bierze udział w kontroli punktów kontrolnych cyklu komórkowego G1/S, intra-S i G2/M, częściowo przez fosforylację p53. ATR reaguje na stres replikacyjny w obecności jednoniciowego DNA (ssDNA). Uruchamia kaskadę aktywacji białek efektorowych, takich jak kinaza Chk1 i składniki szlaku niedokrwistości Fanconiego (FA). Szlaki ATM i ATR ułatwiają naprawę DNA poprzez rekombinację homologiczną (HR). DSB mogą być również naprawiane przez zależną od DNA kinazę białkową (DNA-PK), która koordynuje naprawę poprzez szlak łączenia niehomologicznych końców (NHEJ). 9-1-1 - kompleks złożony z białek RAD9-HUS1RAD1; cdc25 - fosfataza, wpływająca na regulację cyklu komórkowego; ATRIP - białko oddziałujące z kinazą ATR; BRCA1/BRCA2 produkty genów podatności na raka piersi; DNA-PK - kinaza białkowa zależna od DNA; E2F1 - czynnik transkrypcyjny; FANCD2 - podstawowy składnik szlaku FA; Mre11, Rad50, Nbs1 - składniki kompleksu MNR; Rad51 - białko biorące udział w szlaku naprawy DNA; RFC - czynnik replikacyjny; SMC1 - białko zapewniające utrzymanie struktury chromosomów; TIP60 - acetylotransferaza histonowa; TopBP1 - białko 1 wiążące topoizomerazę II; XRCC4-LigIV - kompleks ligacyjny, łączący zerwane końce DNA; yH2AX - wariant histonu H2A (na podstawie: [74]) 
niższego szczebla, które przyczyniają się do DDR [70]. ATM i DNA-PK są aktywowane w odpowiedzi na pęknięcia dwuniciowe (DSB), podczas gdy ATR głównie odpowiada na stres replikacyjny i jest aktywowany $w$ obecności jednoniciowego DNA (ssDNA, single stranded DNA) w zablokowanych widełkach replikacyjnych [71, 72, 73] (ryc. 3).

DSB w DNA mogą doprowadzić do utraty części informacji genetycznej lub śmierci komórki. DSB są rozpoznawane przez kompleks MNR (Mre11, Rad50, Nbs1), który razem z acetylotransferazą histonu TIP60 aktywuje autofosforylację ATM w odpowiedzi na uszkodzenie. ATM aktywuje czynniki efektorowe, takie jak kinaze Chk2 i wariant histonu $\mathrm{H} 2 \mathrm{~A}(\mathrm{yH} 2 \mathrm{AX})$, które inicjują kaskadę rekrutacji dalszych czynników naprawczych do miejsca uszkodzenia DNA w celu zatrzymania cyklu komórkowego, naprawy uszkodzeń lub apoptozy. ATM aktywuje też kolejne białka efektorowe do naprawy DSB w procesie rekombinacji homologicznej (HR, homologous recombination). Uczestniczą w tym geny podatności na raka piersi BRCA1 i BRCA2, jak również białka Rad51 i PALB2 [75] oraz białko SMC1, składnik kompleksu kohezyjnego chromatyd siostrzanych, istotne dla segregacji chromosomów podczas mitozy. Aktywacja szlaku ATM prowadzi też do fosforylacji białka p53, wywołując zatrzymanie cyklu komórkowego lub apoptozę [69, 73] (ryc. 3).

W przeciwieństwie do ATM, DNA-PK promuje szybką naprawę $w$ wyniku niehomologicznego łączenia końców (NHEJ, non-homologous end joining). W tym przypadku DSB są rozpoznawane przez heterodimer Ku70/80, który funkcjonuje jako rusztowanie białek naprawczych, $w$ tym DNA-PK oraz endonukleazy Arthemis i kompleksu ligacyjnego (XLF-XRCC4-DNA ligase IV) dla bezpośredniego łączenia zerwanych końców DNA. NHEJ w przeciwieństwie do HR nie jest ograniczony do fazy S/ G2 cyklu komórkowego, ponieważ nie wymaga obecności chromatyd siostrzanych do procesu naprawy, za to może generować zdecydowanie więcej błędów [76] (ryc. 3).

ATR to kolejny główny koordynator DDR, który jest związany ze stresem replikacyjnym i blokadą widełek replikacyjnych [68, 71]. Stres replikacyjny (RS, replication stress) występuje z powodu spowolnienia lub zatrzymania postępu widełek replikacyjnych lub syntezy DNA i powoduje powstanie dużych obszarów jednoniciowego DNA (ssDNA) związanych przez białka replikacyjne A swoiście wiążące się do obszarów jednoniciowego DNA (RPA). ATR wiąże się ze swoim partnerem regulacyjnym, białkiem ATRIP, które bezpośrednio oddziałuje z RPA, co umożliwia kompleksowi ATR/ATRIP rozpoznanie ssDNA w miejscach zablokowanych widełek replikacyjnych lub uszkodzenia DNA [71, 76]. Ponadto asocjacja RPA/ssDNA rekrutuje kompleks Rad17/ RFC, który ułatwia wiązanie do DNA kolejnego kompleksu:
RAD9-HUS1-RAD1 (9-1-1). Białko Rad9 wykazuje zdolność do oddziaływania z białkiem 1 wiążącym topoizomerazę II (TopBP1), które ułatwia fosforylację kinazy ATR. Aktywowana ATR, z udziałem białka klaspiny, fosforyluje kolejne białka efektorowe, w tym kinazę Chk1 [68, 69, 76]. Aktywacja szlaku ATR inicjuje m.in. zatrzymanie punktu kontrolnego cyklu komórkowego przez fosforylację fosfatazy Cdc25 [77, 78]. Szlak ATR/Chk1 chroni genom przed stresem replikacyjnym, koordynując stabilizację i ponowne uruchomienie widełek replikacyjnych. Mimo że ścieżki ATM i ATR są aktywowane w odpowiedzi na różne uszkodzenia DNA, to mają też wspólne dalsze efektory, w tym białka szlaku niedokrwistości Fanconiego (FA, Fanconi anemia pathway) [79].

Szlak FA wykrywa uszkodzenia DNA wynikające z nieprawidłowego krzyżowania się łańcuchów DNA i niektóre białka efektorowe ATR i ATM są w nim wykorzystywane. Nieprawidłowe krzyżowania między nićmi DNA są rozpoznawane przez kompleks FANCM-FAAP24-MHF, który rekrutuje do miejsc uszkodzeń główny, wielopodjednostkowy kompleks FA. Powoduje to zależną od ATR fosforylację kilku białek FA, w tym podstawowego białka regulatorowego FANCD2. Fosforylacja natomiast wywołuje ubikwitynację FANCD2 przez ligazę ubikwityny E3. Aktywowany FANCD2Ub oddziałuje z białkami naprawczymi yH2AX i BRCA1, które umożliwiają mu wiązanie do miejsca uszkodzenia i rekrutację dalszych białek, takich jak BRCA2 i RAD51 w celu naprawy DNA [79] (ryc. 3).

\section{Sygnalizacja ATM a produktywna replikacja wirusa}

Badania zespołu Laiminsa dostarczyły pierwszych dowodów, że w komórkach zakażonych HPV31 szlak ATM jest konstytutywnie aktywny i warunkuje fosforylację wielu białek efektorowych, takich jak: yH2AX, Chk2, Nbs1, BRCA1, SMC1, p38MAPK i MK2. Wykazały też, że ich wysoki poziom jest utrzymywany w zakażonych komórkach podlegających różnicowaniu [80]. Badania dotyczące infekcji zarówno typem HPV16 jak i HPV18, jednoznacznie potwierdziły, że aktywacja ATM jest kluczowa dla realizacji cyklu replikacyjnego HR-HPV. Wykazano, że w komórkach zakażonych HR-HPV składniki szlaku ATM są gromadzone w ogniskach replikacji wirusa zarówno w niezróżnicowanych jak i zróżnicowanych komórkach nabłonkowych [81]. Pewne z tych czynników, w tym kompleks MRN, białko Rad51 i BRCA1, są niezbędne do naprawy DNA w wyniku rekombinacji homologicznej (HR) i są też konieczne do produktywnej replikacji HR-HPV [82]. HR jest procesem relatywnie wolnym od błędów i HPV może preferencyjnie wykorzystywać tę metodę naprawy, aby utrzymać integralność wirusowego DNA podczas amplifikacji. Ponadto w ogniskach replikacji HPV31 i HPV16 komórek różnicujących się zaobserwowano struktury odpowiadające 
rekombinacji, podczas gdy były one niewykrywalne $w$ fazie utrzymywania infekcji w komórkach niezróżnicowanych. Obserwacje te sugerują, że amplifikacja genomu wirusa podczas różnicowania komórek wymaga HR kierowanej przez ATM [83]. Inicjacja HR wymaga resekcji przerwy dwuniciowej (DSB), którą zapewnia aktywność ATM oraz BRCA1, Rad51 i kompleks naprawczy MRN [84, 85, 86, 87]. Anacker i wsp. potwierdzili, że Rad51 pełni rolę rekombinazy, a Mre11, składnik kompleksu MRN, wykazuje aktywność nukleazy w procesie naprawy typu HR, podczas produktywnej replikacji HPV31 [84].

Dokładny mechanizm, poprzez który szlak ATM promuje amplifikację genomów wirusowych w zróżnicowanych komórkach, nie jest w pełni wyjaśniony. Jedna z teorii zakłada, że replikacja wirusa, w komórkach niezróżnicowanych i w dolnych warstwach nabłonka, zachodzi w wyniku dwukierunkowej replikacji typu Theta $(\theta)$. Istnieją dowody, które sugerują, że genomy wirusa podczas amplifikacji w komórkach podlegających różnicowaniu mogą przejść w replikację typu toczącego się koła. Taki typ replikacji może wymagać czynników HR, zabezpieczanych przez ATM, do rozwiązania konkatamerycznych form pośrednich replikacji [88]. Niedawne badania wykazały, że do produktywnej replikacji HPV31 wymagane jest również białko SMC1 [89, 90]. Rola SMC1 w produktywnej replikacji wirusa nie jest wyjaśniona, ale SMC1 rekrutuje się do genomu wirusa w kompleksie z białkami izolującymi CTCF, które uczestniczą w tworzeniu pętli chromatyny i kotwiczeniu DNA. Uważa się, że asocjacja SMC1-CTCF, poza wpływem na rekrutację czynników naprawy DNA do wirusowego genomu podczas rekombinacji, ma wpływ na replikację wirusa, a także jego utrzymywanie i kotwiczenie do chromosomów gospodarza oraz umożliwia większy dostęp do mechanizmów replikacji [90]. Wykazano też, że podczas produktywnej replikacji HPV31 wzrasta wiązanie yH2AX do genomów wirusa, co sugeruje, że $\gamma \mathrm{H} 2 \mathrm{AX}$ może służyć do montowania czynników naprawy HR w miejscach wirusowej replikacji. Białka SIRT1 i TIP60 mogą modyfikować wirusową chromatynę, aby zapewnić rekrutację czynników HR (MNR, BRCA1 i RAD51) do produktywnej replikacji HPV [87, 90].

Aktywacja ATM zachodzi w sposób zależny od białka E7 (ryc. 4). Badania modelowe w organotypowych kulturach wykazały, że ekspresja samego białka E7 z HPV18 powoduje aktywacje ATM, Chk2 i Chk1 w warstwach ponadpodstawowych. Oznacza to, że w komórkach różnicujących się E7 przyczynia się do produktywnej replikacji wirusa przez aktywację szlaku ATM. E7 HPV31 reguluje ATM poprzez białko STAT5, regulator immunologiczny, który też jest wymagany do produktywnej replikacji. W jaki sposób STAT5 prowadzi do aktywacji ATM, nie jest jeszcze wiadome, sugeruje się, że STAT5 może uczestniczyć w aktywacji TIP60. Wiadomo, że acetylotransferaza histonowa TIP60 jest wymagana do aktywacji ATM w komórkach zakażonych HPV oraz do amplifikacji genomów wirusa w komórkach po różnicowaniu [87]. Ekspresja E7 jest wystarczająca do zwiększenia poziomów białek tworzących kompleks naprawczy MNR (Mre11, Rad50, Nbs1) oraz BRCA1 i Rad51, które są wymagane do amplifikacji genomów w zróżnicowanych komórkach [84, 87]. Istnieją dowody wskazujące, że deacetylaza SIRT1 może, przynajmniej częściowo, kontrolować rekrutację białka Nbs1 (składnik kompleksu MNR) i Rad51 do genomów wirusa. Obecność wysokich poziomów tych białek jest argumentem wspierającym prawdopodobną rolę HR w produktywnej replikacji wirusa [87]. Białko E7 przyczynia się do produktywnej replikacji wirusa również przez zwiększenie okresu półtrwania czynników naprawy, zapewniając wysoki poziom wydajnej syntezy wirusowego DNA [91, 92]. Ekspresja samej helikazy E1 w HR-HPV i LR-HPV jest wystarczająca do aktywacji szlaku ATM, która może zachodzić przez indukowanie DSBs z powodu zdolności E1 do niespecyficznego wiązania i rozplatania DNA. W obecności białka E2, E1 jest rekrutowane do wirusowego Ori razem $\mathrm{z}$ wieloma składnikami ATM i ATR [93]. W jaki sposób aktywność ATM jest regulowana przez E7 versus E1 podczas cyklu replikacji wirusa, pozostaje do wyjaśnienia.

\section{Sygnalizacja ATR a produktywna replikacja HPV}

W kilku niezależnych badaniach wykazano, że replikacja HPV aktywuje szlak ATR. Obserwowano, że zahamowanie aktywności ATR zmniejsza liczbę episomów HPV16 i HPV31 w niezróżnicowanych komórkach i całkowicie hamuje produktywną replikację HPV31 w zróżnicowanych komórkach [91, 95, 96]. Analiza białek RPA w ogniskach replikacji HPV31 ujawniła ich fosforylację w pozycji Ser33, co wskazywało zarówno na obecność RS jak i aktywność kinazy ATR w tym procesie [82, 97]. Niedawne badania jednoznacznie wskazują, że HR-HPV mogą wymagać aktywności ATR we wszystkich trzech fazach replikacji [81, 91, 92]. Badanie wpływu aktywności szlaku ATR na replikację wirusa we wczesnych fazach infekcji głównie opiera się na wykorzystywaniu transfekcji komórek genomem HR-HPV, która naśladuje wczesną fazę infekcji w cyklu replikacyjnym wirusa. Transfekcja komórek U20S wirusem HPV18 wykazała aktywację ATR i akumulację składników szlaku ATR ( $\mathrm{yH} 2 \mathrm{AX}$, ATRIP i TOPB1) w ogniskach replikacji wirusa, w sposób zależny od E1 [92]. Wyniki te sugerują, że początkowa amplifikacja genomów HR-HPV może powodować RS, który aktywuje szlak ATR. Analiza elektroforetyczna 2D replikacji genomów w fazie utrzymywania infekcji ujawniła struktury odpowiadające dwukierunkowej replikacji typu $\theta$ (theta), a także replikacji jednokierunkowej, która może obejmować rekombinację. 


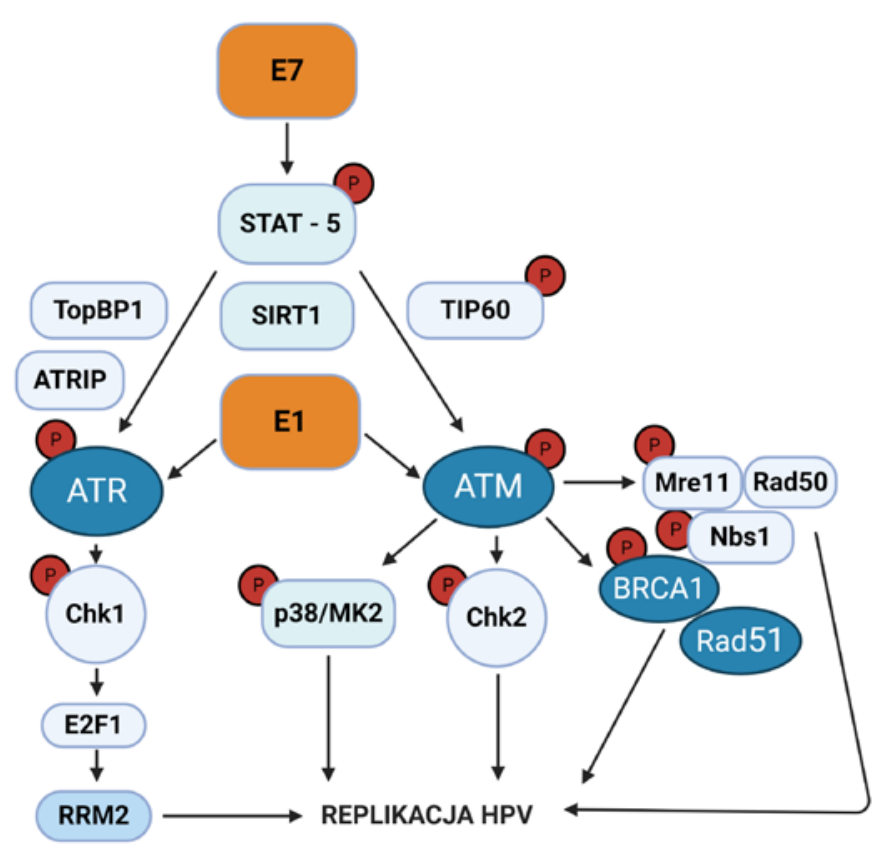

Created in BioRender

Rycina 4. Schemat regulacji komórkowych szlaków naprawy DNA ATM i ATR przez wirusowe białka E7 i E1 HR-HPV w celu promowania replikacji genomu HPV. Aktywacja ATM jest kluczowa dla naprawy DNA drogą rekombinacji homologicznej (HR) (rekrutuje białka Mre11, Nbs1, Rad50 oraz BRCA1 i Rad51). Aktywacja Chk2 i p38/Mk2 jest wymagana dla produktywnej amplifikacji wirusa. Szlak ATR prowadzi do aktywacji Chk1, która powoduje wzrost poziomu białek E2F1. Natomiast E2F1 powoduje wzrost ekspresji RRM2 w celu zaspokojenia zapotrzebowania na dNTP niezbędne do replikacji genomu wirusa. Mre11, Rad50, Nbs1 - składniki kompleksu MNR; p38/MK2 - kinazy z rodziny MAPK; RRM2 - mała podjednostka kompleksu reduktazy rybonukleotydowej; SIRT1 - deacetylaza zależna od NAD; STAT5 czynnik transkrypcyjny (na podstawie: [94])

Wyniki te sugerują, że początkowe rundy replikacji wirusa mogą zachodzić z wykorzystaniem dwóch różnych mechanizmów [92]. Chociaż nie zidentyfikowano swoistych czynników naprawy DNA, które są niezbędne do replikacji w fazie początkowej infekcji, to badania te wskazują, że rekombinacja może być ważna zarówno w początkowej amplifikacji genomów wirusowych, jak i produktywnej amplifikacji po różnicowaniu [73, 83]. Aktywacja szlaku ATR/ Chk1 jest wymagana zarówno do stabilnego utrzymania episomów wirusowych [91, 95, 96], jak i do produktywnej replikacji wirusa [91, 95].

Zarówno E7, jak i E1 mogą niezależnie aktywować szlak ATR/Chk1 [81, 84, 91] (ryc. 4). E7 indukuje aktywację ATR/ Chk1 przez wzrost ekspresji TopBP1 za pośrednictwem STAT5 i SIRT1 [91]. Mechanizm, za pomocą którego E1 indukuje aktywność ATR/Chk1, nie został jeszcze w pełni poznany. Aktywacja może wystąpić albo w wyniku RS wynikającego z zablokowanych widełek replikacyjnych lub DSB w ogniskach replikacji wirusa albo przez nieswoiste wiązanie i rozwijanie komórkowego DNA. Szlak ATR jest konstytutywnie aktywny w komórkach HPV-dodatnich [83, 91], co sugeruje, że komórki zainfekowane wirusem są stale pod wpływem RS. Ekspresja białek E6 i E7 wysokiego ryzyka indukuje RS przez nieplanowane wejście różnicujących się komórek do cyklu komórkowego, promując komórkową syntezę DNA przy braku wystarczającej podaży nukleotydów [98, 99].

Wykazano niedawno, że HPV wykorzystuje aktywację ATR do utrzymywania aktywnej sygnalizacji transkrypcyjnej E2F [95]. W odpowiedzi na RS, trwała, zależna od E2F transkrypcja jest ważna dla przeżycia komórek, ponieważ zapewnia ekspresję genów komórkowych, które ułatwiają replikację, naprawę DNA i syntezę nukleotydów [100, 101]. Anacker i wsp. wykazali, że HPV31 wykorzystuje szlak ATR/Chk1/E2F1 do zwiększenia poziomów RRM2, małej podjednostki kompleksu reduktazy rybonukleotydowej, w sposób zależny od E7 [95] (ryc. 4). RRM2 wraz z dużą podjednostką RRM1 są niezbędne do konwersji rybonukleotydów w deoksyrybonukleotydy zapewniając dNTP do replikacji, naprawy DNA i przeżycia komórki. RRM2 jest wymagany do syntezy de novo dNTP i jest konieczny do utrzymania puli nukleotydów do produktywnej replikacji genomu HPV w komórkach [95]. Wyniki te wskazują, że indukowana przez E7 aktywacja szlaku ATR/Chk1/E2F1/ 
RRM2 jest szczególnie ważna dla produktywnej replikacji wirusa w zróżnicowanych komórkach nabłonka, zatem w środowisku zatrzymanym w fazie G2 i przy ograniczonych substratach do replikacji [84]. Wysoki poziom E2F1, RRM2 i dNTP w komórkach zakażonych HR-HPV sugeruje, że zwiększenie aktywności ATR i Chk1 może być dodatkową strategią wykorzystywaną przez HPV do replikacji w obecności trwałego RS. Możliwość terapeutycznego celowania w odpowiedź RS w zakażeniach HPV jest szczególnie obiecująca w świetle dwóch ostatnich badań klinicznych wykazujących skuteczność radio/ chemioterapii w połączeniu z inhibitorem RRM2 - triapiną, w zaawansowanym raku szyjki macicy [102].

\section{Konsekwencje wykorzystywania ścieżek DDR w replikacji wirusa}

Ogniska replikacji HPV zwykle tworzą się w pobliżu typowych kruchych miejsc chromosomów gospodarza. Typowe kruche miejsca to obszary chromosomów o zwiększonej częstości pęknięć lub złamań w obrębie chromatyd, przez co są podatne na stres związany z replikacją i rekrutują czynniki naprawy DNA w celu utrzymania stabilności genomowej [103, 104]. HPV może preferencyjnie replikować się $\mathrm{w}$ sąsiedztwie kruchych miejsc ze względu na łatwy dostęp do czynników naprawy DNA, co ułatwia wirusowi replikację ukierunkowaną na rekombinację. Indukcja DSBs i RS podczas produktywnej replikacji genomu wirusa [105] w pobliżu kruchych miejsc, również podatnych na DSBs, sprzyja integracji genomu HPV z DNA gospodarza [97]. Proces integracji genomu wirusa najczęściej zachodzi z przerwaniem ciągłości sekwencji w obrębie ORF E2 i/lub E1 genomu i prawie zawsze powoduje zwiększenie ekspresji onkogenów E6 i E7 [106]. Dysfunkcja wirusowych białek replikacyjnych (E1 i/lub E2) sprawia, że integracja jest równoznaczna z zakończeniem produkcji nowych wirusów, a deregulacja ekspresji E6 i E7 sprzyja proliferacyjnemu i klonalnemu wzrostowi komórek zawierających zintegrowane wirusowe DNA. Ścisłe powiązanie ognisk replikacji HPV z obszarami uszkodzenia DNA komórki zwiększa ryzyko przypadkowej integracji genomu wirusa i wyjaśnia tendencję HPV do integracji w typowych kruchych miejscach DNA gospodarza [107]. Badania w laboratorium Galloway wykazały, że białka E6 i E7 wysokiego ryzyka osłabiają naprawę komórkowych DSB w wyniku HR. Choć prawdopodobnie zapewnia to większą dostępność czynników HR do replikacji wirusów, to jednak obecność trwałych, nienaprawionych pęknięć DNA komórkowego prawdopodobnie i tak zwiększa szansę na integrację genomu wirusa [108]. Te zdarzenia integracyjne mogą się przyczynić do onkogenezy HPV przez indukowanie niestabilności genomowej za pośrednictwem E6 i E7. W nowotworach związanych z HR-HPV wirusowe DNA często jest zintegrowane $z$ DNA gospodarza w obszarze typowych kruchych miejsc [106, 109, 110].

\section{Szlak FA w replikacji i transformacji wirusowej}

Szlaki naprawy DNA gospodarza odgrywają złożoną rolę w cyklu replikacyjnym HPV, a utrata ich funkcji może upośledzać replikację wirusa i promować rozwój nowotworów związanych z HPV. Niedokrwistość Fanconiego (FA) to genetycznie heterogeniczne zaburzenie spowodowane mutacją $w$ jednym lub większej liczbie genów szlaku FA. Pacjenci z FA są bardziej podatni na raka płaskonabłonkowego (SCC, squamous cell carcinoma), szczególnie jamy ustnej i okolic odbytu, obszarów odpowiadających preferowanym miejscom zakażenia HPV. DNA HPV wykryto w ponad $80 \%$ SCC od pacjentów z FA w porównaniu do $36 \%$ od pacjentów kontrolnych, co sugeruje, że utrata aktywności szlaku FA może promować transformację wirusową [111]. Badania molekularne wykazały, że białko E7 HR-HPV reguluje w górę transkrypcję genów FA mechanizmem zależnym od Rb [112, 113]. Ponadto E7 HR-HPV, ale nie LR-HPV, jest wystarczające do aktywacji szlaku FA i stymuluje rekrutację zarówno FANCD2, jak i BRCA2 do chromatyny [111]. Utrata FANCD2 lub FANCA, głównych składowych szlaku FA, prowadzi do potranskrypcyjnej akumulacji E7 i stymuluje hiperplastyczny wzrost w komórkach HPV-dodatnich. Ekspresja E7 powoduje też wzrost niestabilności chromosomów w fibroblastach z niedoborem FA i zwiększa podatność do SCC głowy i szyi u myszy z nokautem FANCD2 [114, 115]. Pomimo tych ustaleń i korelacji między utratą aktywności szlaku FA a rakiem związanym z HPV, dokładna rola szlaku FA w cyklu replikacyjnym HPV nadal nie jest w pełni poznana [116]. Wykazano, że FANCD2 umiejscawia się w ogniskach replikacji wirusa HPV31 i wiąże się z kilkoma miejscami wzdłuż genomu wirusowego. Wiązanie to występuje zarówno w niezróżnicowanych jak i zróżnicowanych komórkach, ale zmniejsza się po różnicowaniu, co sugeruje, że szlak FA może być zaangażowany przede wszystkim w replikację genomów HPV w niezróżnicowanych komórkach [116]. Ponadto zahamowanie aktywności FANCD2 doprowadza do spadku utrzymywania episomalnej formy genomów wirusa w niezróżnicowanych komórkach, co może promować ich integrację z DNA gospodarza i może wyjaśnić zwiększoną podatność na nowotwory związane z HPV u pacjentów z FA [116]. Chociaż niewiele wiadomo na temat roli szlaku FA w fazie amplifikacji produktywnej HPV, to pewne obserwacje wskazują na prawdopodobny udział FA w promowaniu HR jako mechanizmu naprawy DNA. Wykazano, że FANCD2- 
Ub pośredniczy w rekrutacji czynników HR, w tym BRCA1, BRCA2 i PALB2 do miejsc uszkodzenia i uczestniczy w formowaniu ognisk RAD51 [117]. Ponadto uszkodzenie FANCD2 stymuluje fosforylację kinazy DNA-PK związanej z NHEJ. Komórki z niedoborem FA wykazują wyższe wskaźniki mikrodelecji i insercji, co często wskazuje na nadczynność naprawy NHEJ [118]. Możliwe, że HPV aktywuje szlak FA bezpośrednio lub pośrednio przez szlak ATR i rekrutuje FANCD2 do genomu wirusa w celu rekrutacji białek HR do wirusowego DNA podczas replikacji [117]. Pełne zrozumienie roli szlaku FA w cyklu replikacyjnym wirusa HPV wymaga jeszcze dogłębnych badań.

\section{Podsumowanie}

Wirus HPV, aby zapewnić sobie optymalne środowisko do replikacji, wykorzystuje specyficzne szlaki komórki gospodarza, które regulują różnicowanie nabłonka, proliferację komórek oraz ułatwiają naprawę uszkodzonego DNA. Ograniczenie wysokiego poziomu ekspresji genów wirusowych, replikacji jak i wytwarzania wirionów do najwyższych warstw nabłonka, chroni komórki zakażone HPV przed odpowiedzią immunologiczną gospodarza. Taka czasowa regulacja ekspresji genów HPV jest możliwa dzięki różnemu wykorzystywaniu wczesnych i późnych promotorów i miejsc poliadenylacji oraz przez alternatywne składanie transkryptów. Współdziałanie białek E6, E7, E1, E2, E4 i E5 podczas różnicowania nabłonka umożliwia HPV stworzenie środowiska wspierającego produktywną replikację w niedzielących się komórkach. Białka E6 i E7 odgrywają ważną rolę $\mathrm{w}$ promowaniu replikacji wirusa i ułatwiają mu przetrwanie, modulując wrodzoną odpowiedź immunologiczną. Stale rośnie zakres poznania mechanizmów wykorzystywanych przez HPV do regulacji fazy produktywnej wirusowego cyklu replikacji, w tym szczególnie sposobów aktywacji i wykorzystywania ścieżek naprawy DNA do amplifikacji genomów wirusowych. Jednak wciąż wiele pytań pozostaje bez odpowiedzi. Nadal nie wiadomo, w jaki sposób HR-HPV manipulują szlakami komórkowymi w celu ułatwienia replikacji wirusa oraz jak podporządkowanie tych szlaków wirusowi może wpłynąć na integralność genomu komórki. Pełne zrozumienie mechanizmów, dzięki którym HPV ustanawia kompetentne środowisko replikacji w całym cyklu rozwojowym wirusa, jest ważne, aby zidentyfikować cele komórkowe, które mogłyby być wykorzystywane terapeutycznie w chorobach związanych z HPV.

\section{Wykaz skrótów}

ATM - zmutowana ataksja teleangiektazja (ataxia telangiectasia mutated); główna kinaza jednego ze szlaków naprawy DNA, ATR - ataksja teleangiektazja związana z białkiem Rad3 (ataxia telangiectasia and Rad3-related protein); główna kinaza jednego ze szlaków naprawy DNA, DDR - odpowiedź na uszkodzenia DNA (DNA damage response), DNA-PK - kinaza białkowa zależna od DNA (DNA-dependent protein kinase); główna kinaza jednego ze szlaków naprawy DNA, DSB - dwuniciowe pęknięcie nici DNA (double strand break), FA - szlak reakcji niedokrwistości Fanconiego, HPV- wirus brodawczaka ludzkiego (human papillomavirus), HR - rekombinacja homologiczna (homologous recombination), HR-HPV - typy wirusa HPV o wysokim potencjale onkogennym (wysokiego ryzyka) (high-risk HPV), LCR - długi region kontrolny (long control region), LR-HPV - typy wirusa HPV o niskim potencjale onkogennym (niskiego ryzyka) (low-risk HPV), miRNA - mikro-RNA (micro-RNA), MNR - kompleks złożony z białek Mre11, Rad50, Nbs, rozpoznający DSB, NHEJ - naprawa DNA w wyniku niehomologicznego łączenia końców (nonhomologous end joining), pHR-HPV - typy wirusa HPV o prawdopodobnie wysokim potencjale onkogennym (prawdopodobnie wysokiego ryzyka) (probably high-risk HPV), Rb - białko siatkówczaka (retinoblastoma), RS - stres replikacyjny (replication stress), SCC - rak płaskonabłonkowy (squamous cell carcinoma).

\section{Konflikt interesów}

Autorki deklarują brak potencjalnych konfliktów interesów.

\section{Piśmiennictwo}

[1] Egawa N., Egawa K., Griffin H., Doorbar J.: Human papillomaviruses; epithelial tropisms, and the development of neoplasia. Viruses, 2015; 7: 3863-3890

[2] Chan C.K., Aimagambetova G., Ukybassova T., Kongrtay K., Azizan A.: Human papillomavirus infection and cervical cancer: Epidemiology, screening, and vaccination - review of current perspectives. J. Oncol., 2019; 2019: 3257939

[3] DiGiuseppe S., Bienkowska-Haba M., Guion L.G., Sapp M.: Cruising the cellular highways: How human papillomavirus travels from the surface to the nucleus. Virus Res., 2017; 231: 1-9

[4] International Agency for Research on Cancer: IARC monographs on the evaluation of carcinogenic risks to humans. Biologica agents, volume $100 \mathrm{~B}, \mathrm{~A}$ review of human carcinogenesis. International Agency for Research on Cancer, Lyon 2012 
[5] Doorbar J., Quint W., Banks L., Bravo I.G., Stoler M., Broker T.R., Stanley M.A.: The biology and life-cycle of human papillomaviruses. Vaccine, 2012; 30: F55-F70

[6] Gillison M.L., Chaturvedi A.K., Anderson W.F., Fakhry C.: Epidemiology of human papillomavirus-positive head and neck squamous cell carcinoma. J. Clin. Oncol., 2015; 33: 3235-3242

[7] Osazuwa-Peters N., Massa S.T., Simpson M.C., Adjei Boakye E., Varvares M.A.: Survival of human papillomavirus-associated cancers: Filling in the gaps. Cancer, 2018; 124: 18-20

[8] Khallouf H., Grabowska A.K., Riemer A.B.: Therapeutic vaccine strategies against human papillomavirus. Vaccines, 2014; 2: 422462

[9] Wright T.C. Jr., Massad L.S., Dunton C.J., Spitzer M., Wilkinson E.J., Solomon D., 2006 American Society for Colposcopy and Cervical Pathology-sponsored Consensus Conference: 2006 consensus guidelines for the management of women with abnormal cervical cancer screening tests. Am. J. Obstet. Gynecol., 2007; 197: 346-355

[10] Burley M., Roberts S., Parish J.L.: Epigenetic regulation of human papillomavirus transcription in the productive virus life cycle. Sem. Immunopathol., 2020; 42: 159-171

[11] McBride A.A.: Oncogenic human papillomaviruses. Philos. Trans. R. Soc. Lond. B Biol. Sci., 2017; 372: 20160273

[12] McBride A.A.: The papillomavirus E2 proteins. Virology, 2013; 445: $57-79$

[13] Bergvall M., Melendy T., Archambault J.: The E1 proteins. Virology, 2013; 445: 35-56

[14] Graham S.V.: Keratinocyte differentiation-dependent human papillomavirus gene regulation. Viruses, 2017; 9: 245

[15] Laaneväli A., Ustav M., Ustav E., Piirsoo M.: E2 protein is the major determinant of specificity at the human papillomavirus origin of replication. PLoS One, 2019; 14: e0224334

[16] Sitz J., Blanchet S.A., Gameiro S.F., Biquand E., Morgan T.M., Galloy M., Dessapt J., Lavoie E.G., Blondeau A., Smith B.C. i wsp.: Human papillomavirus E7 oncoprotein targets RNF168 to hijack the host DNA damage response. Proc. Natl. Acad. Sci. USA, 2019; 116: 19552-19562

[17] Squarzanti D.F., Sorrentino R., Landini M.M., Chiesa A., Pinato S., Rocchio F., Mattii M., Penengo L., Azzimonti B.: Human papillomavirus type $16 \mathrm{E} 6$ and E7 oncoproteins interact with the nuclear p53-binding protein 1 in an in vitro reconstructed 3D epithelium: New insights for the virus-induced DNA damage response. Virol. J., 2018; 15: 176

[18] Doorbar J.: The E4 protein; structure, function and patterns of expression. Virology, 2013; 445: 80-98

[19] DiMaio D., Petti L.M.: The E5 proteins. Virology, 2013; 445: 99114

[20] Dreer M., van de Poel S., Stubenrauch F.: Control of viral replication and transcription by the papillomavirus E8^E2 protein. Virus Res., 2017; 231: 96-102

[21] Zhang W., Kazakov T., Popa A., DiMaio D.: Vesicular trafficking of incoming human papillomavirus 16 to the Golgi apparatus and endoplasmic reticulum requires $\mathrm{y}$-secretase activity. mBio, 2014; 5: e01777-14

[22] DiGiuseppe S., Luszczek W., Keiffer T.R., Bienkowska-Haba M., Guion L.G., Sapp M.J.: Incoming human papillomavirus type 16 genome resides in a vesicular compartment throughout mitosis. Proc. Natl. Acad. Sci. USA, 2016; 113: 6289-6294

[23] Aydin I., Weber S., Snijder B., Ventayol P.S., Kühbacher A., Becker M., Day P.M., Schiller J.T., Kann M., Pelkmans L. i wsp.: Large scale RNAi reveals the requirement of nuclear envelope breakdown for nuclear import of human papillomaviruses. PLoS Pathog, 2014; 10: e1004162

[24] Everett R.D.: The spatial organization of DNA virus genomes in the nucleus. PLoS Pathog, 2013; 9: e1003386

[25] McBride A.A.: Mechanisms and strategies of papillomavirus replication. Biol. Chem., 2017; 398: 919-927

[26] Moody C.A., Laimins L.A.: Human papillomavirus oncoproteins: Pathways to transformation. Nat. Rev. Cancer, 2010; 10: 550-560

[27] Sanders C.M., Stenlund A.: Transcription factor-dependent loading of the E1 initiator reveals modular assembly of the papillomavirus origin melting complex. J. Biol. Chem., 2000; 275: 3522-3534

[28] Westrich J.A., Warren C.J., Pyeon D.: Evasion of host immune defenses by human papillomavirus. Virus Res., 2017; 231: 21-33

[29] Smith J.A., White E.A., Sowa M.E., Powell M.L., Ottinger M., Harper J.W., Howley P.M.: Genome-wide siRNA screen identifies SMCX, EP400, and Brd4 as E2-dependent regulators of human papillomavirus oncogene expression. Proc. Natl. Acad. Sci. USA, 2010; 107: 3752-3757

[30] Graham S.V.: The human papillomavirus replication cycle, and its links to cancer progression: A comprehensive review. Clin. Sci., 2017; 131: 2201-2221

[31] Gunasekharan V.K., Li Y., Andrade J., Laimins L.A.: Post-transcriptional regulation of KLF4 by high-risk human papillomaviruses is necessary for the differentiation-dependent viral life cycle. PLoS Pathog., 2016; 12: e1005747

[32] Davy C., McIntosh P., Jackson D.J., Sorathia R., Miell M., Wang Q., Khan J., Soneji Y., Doorbar J.: A novel interaction between the human papillomavirus type $16 \mathrm{E} 2$ and E1^ $\mathrm{E} 4$ proteins leads to stabilization of E2. Virology, 2009; 394: 266-275

[33] Egawa N., Wang Q., Griffin H.M., Murakami I., Jackson D., Mahmood R., Doorbar J.: HPV16 and 18 genome amplification show different E4-dependence, with 16E4 enhancing E1 nuclear accumulation and replicative efficiency via its cell cycle arrest and kinase activation functions. PLOS Pathog., 2017; 13: e1006282

[34] Prescott E.L., Brimacombe C.L., Hartley M., Bell I., Graham S., Roberts S.: Human papillomavirus type $1 \mathrm{E} 1^{\wedge} \mathrm{E} 4$ protein is a potent inhibitor of the serine-arginine (SR) protein kinase SRPK1 and inhibits phosphorylation of host SR proteins and of the viral transcription and replication regulator E2. J. Virol., 2014; 88: 1259912611

[35] Ashrafi G.H., Haghshenas M., Marchetti B., Campo M.S.: E5 protein of human papillomavirus 16 downregulates HLA class I and 
interacts with the heavy chain via its first hydrophobic domain. Int. J. Cancer, 2006; 119: 2105-2112

[36] Wetherill L.F., Holmes K.K., Verow M., Müller M., Howell G., Harris M., Fishwick C., Stonehouse N., Foster R., Blair G.E. i wsp.: High-risk human papillomavirus E5 oncoprotein displays channelforming activity sensitive to small-molecule inhibitors. J. Virol., 2012; 86: 5341-5351

[37] Graham S.V.: Human papillomavirus: Gene expression, regulation and prospects for novel diagnostic methods and antiviral therapies. Future Microbiol., 2010; 5: 1493-1506

[38] Sakakibara N., Chen D., McBride A.A.: Papillomaviruses use recombination-dependent replication to vegetatively amplify their genomes in differentiated cells. PLoS Pathog., 2013; 9: e1003321

[39] Banerjee N.S., Wang H.K., Broker T.R., Chow L.T.: Human papillomavirus (HPV) E7 induces prolonged G2 following $S$ phase reentry in differentiated human keratinocytes. J. Biol. Chem., 2011; 286: 15473-15482

[40] Yuan C.H., Filippova M., Duerksen-Hughes P.: Modulation of apoptotic pathways by human papillomaviruses (HPV): Mechanisms and implications for therapy. Viruses, 2012; 4: 3831-3850

[41] Songock W.K., Kim S.M., Bodily J.M.: The human papillomavirus E7 oncoprotein as a regulator of transcription. Virus Res., 2017; 231: $56-75$

[42] Roman A., Munger K.: The papillomavirus E7 proteins. Virology, 2013; 445: 138-168

[43] Kho E.Y., Wang H.K., Banerjee N.S., Broker T.R., Chow L.T.: HPV-18 E6 mutants reveal p53 modulation of viral DNA amplification in organotypic cultures. Proc. Natl. Acad. Sci. USA, 2013; 110 : 7542-7549

[44] White E.A., Kramer R.E., Tan M.J., Hayes S.D., Harper J.W., Howley P.M.: Comprehensive analysis of host cellular interactions with human papillomavirus E6 proteins identifies new E6 binding partners and reflects viral diversity. J. Virol., 2012; 86: 1317413186

[45] Basukala O., Sarabia-Vega V., Banks L.: Human papillomavirus oncoproteins and post-translational modifications: Generating multifunctional hubs for overriding cellular homeostasis. Biol. Chem., 2020; 401: 585-599

[46] Pacini L., Savini C., Ghittoni R., Saidj D., Lamartine J., Hasan U.A., Accardi R., Tommasino M.: Downregulation of Toll-like receptor 9 expression by beta human papillomavirus 38 and implications for cell cycle control. J. Virol., 2015; 89: 11396-11405

[47] Ganguly N., Parihar S.P.: Human papillomavirus E6 and E7 oncoproteins as risk factors for tumorigenesis. J. Biosci., 2009; 34 : 113-123

[48] Reiser J., Hurst J., Voges M., Krauss P., Münch P., Iftner T., Stubenrauch F.: High-risk human papillomaviruses repress constitutive kappa interferon transcription via E6 to prevent pathogen recognition receptor and antiviral-gene expression. J. Virol., 2011; 85: 11372-11380

[49] James C.D., Roberts S.: Viral interactions with PDZ domain-containing proteins - an oncogenic trait? Pathogens, 2016; 5: 8
[50] Schmitt M., Dalstein V., Waterboer T., Clavel C., Gissmann L., Pawlita M.: The HPV16 transcriptome in cervical lesions of different grades. Mol. Cell. Probes, 2011; 25: 260-265

[51] Wongworawat Y.C., Filippova M., Williams V.M., Filippov V., Duerksen-Hughes P.J.: Chronic oxidative stress increases the integration frequency of foreign DNA and human papillomavirus 16 in human keratinocytes. Am. J. Cancer Res., 2016; 6: 764-780

[52] Heino P., Zhou J., Lambert P.F.: Interaction of the papillomavirus transcription/replication factor, E2, and the viral capsid protein, L2. Virology, 2000; 276: 304-314

[53] Wang J.W., Roden R.B.: L2, the minor capsid protein of papillomavirus. Virology, 2013; 445: 175-186

[54] Bodily J.M., Hennigan C., Wrobel G.A., Rodriguez C.M.: Regulation of the human papillomavirus type 16 late promoter by E7 and the cell cycle. Virology, 2013; 443: 11-19

[55] Grm H.S., Massimi P., Gammoh N., Banks L.: Crosstalk between the human papillomavirus E2 transcriptional activator and the E6 oncoprotein. Oncogene, 2005; 24: 5149-5164

[56] Friedman R.C., Farh K.K., Burge C.B., Bartel D.P.: Most mammalian mRNAs are conserved targets of microRNAs. Genome Res., 2009; 19: 92-105

[57] Graham S.V., Faizo A.A.: Control of human papillomavirus gene expression by alternative splicing. Virus Res., 2017; 231: 83-95

[58] Li Y., Cai Q., Lin L., Xu C.: MiR-875 and miR-3144 switch the human papillomavirus $16 \mathrm{E} 6 / \mathrm{E}^{*}$ mRNA ratio through the EGFR pathway and a direct targeting effect. Gene, 2018; 679: 389-397

[59] Chirayil R., Kincaid R.P., Dahlke C., Kuny C.V., Dälken N., Spohn M., Lawson B., Grundhoff A., Sullivan C.S.: Identification of virusencoded microRNAs in divergent papillomaviruses. PLoS Pathog., 2018; 14: e1007156

[60] Qian K., Pietilä T., Rönty M., Michon F., Frilander M.J., Ritari J., Tarkkanen J., Paulín L., Auvinen P., Auvinen E.: Identification and validation of human papillomavirus encoded microRNAs. PLoS One, 2013; 8: e70202

[61] Li Y., Liu J., Yuan C., Cui B., Zou X., Qiao Y.: High-risk human papillomavirus reduces the expression of microRNA-218 in women with cervical intraepithelial neoplasia. J. Int. Med. Res., 2010; 38: $1730-1736$

[62] Wang X., Wang H.K., McCoy J.P., Banerjee N.S., Rader J.S., Broker T.R., Meyers C., Chow L.T., Zheng Z.M.: Oncogenic HPV infection interrupts the expression of tumor-suppressive miR-34a through viral oncoprotein E6. RNA, 2009; 15: 637-647

[63] Melar-New M., Laimins L.A.: Human papillomaviruses modulate expression of microRNA 203 upon epithelial differentiation to control levels of p63 proteins. J. Virol., 2010; 84: 5212-5221

[64] Ofir M., Hacohen D., Ginsberg D.: MiR-15 and miR-16 are direct transcriptional targets of E2F1 that limit E2F-induced proliferation by targeting cyclin E. Mol. Cancer Res., 2011; 9: 440-447

[65] Wang X., Wang H.K., Li Y., Hafner M., Banerjee N.S., Tang S., Briskin D., Meyers C., Chow L.T., Xie X. i wsp.: microRNAs are biomarkers of oncogenic human papillomavirus infections. Proc. Natl. Acad. Sci. USA, 2014; 111: 4262-4267 
[66] Honegger A., Schilling D., Bastian S., Sponagel J., Kuryshev V., Sültmann H., Scheffner M., Hoppe-Seyler K., Hoppe-Seyler F.: Dependence of intracellular and exosomal microRNAs on viral E6/E7 oncogene expression in HPV-positive tumor cells. PLoS Pathog, 2015; 11: e1004712

[67] Gunasekharan V., Laimins L.A.: Human papillomaviruses modulate microRNA 145 expression to directly control genome amplification. J. Virol., 2013; 87: 6037-6043

[68] Maréchal A., Zou L.: DNA damage sensing by the ATM and ATR kinases. Cold Spring Harb. Perspect. Biol., 2013; 5: a012716

[69] Matsuoka S., Ballif B.A., Smogorzewska A., McDonald E.R.3rd, Hurov K.E., Luo J., Bakalarski C.E., Zhao Z., Solimini N., Lerenthal Y. i wsp.: ATM and ATR substrate analysis reveals extensive protein networks responsive to DNA damage. Science, 2007; 316: 1160-1166

[70] Blackford A.N., Jackson S.P.: ATM, ATR, and DNA-PK: The trinity at the heart of the DNA damage response. Mol. Cell, 2017; 66: 801-817

[71] Nam E.A., Cortez D.: ATR signalling: More than meeting at the fork. Biochem. J., 2011; 436: 527-536

[72] Sulli G., Di Micco R., d'Adda di Fagagna F.: Crosstalk between chromatin state and DNA damage response in cellular senescence and cancer. Nat. Rev. Cancer, 2012; 12: 709-720

[73] Zeman M.K., Cimprich K.A.: Causes and consequences of replication stress. Nat. Cell Biol., 2014; 16: 2-9

[74] Spriggs C.C., Laimins L.A.: Human papillomavirus and the DNA damage response: Exploiting host repair pathways for viral replication. Viruses, 2017; 9: 232

[75] Sy S.M., Huen M.S., Chen J.: PALB2 is an integral component of the BRCA complex required for homologous recombination repair. Proc. Natl. Acad. Sci. USA, 2009; 106: 7155-7160

[76] Hollingworth R., Grand R.J.: Modulation of DNA damage and repair pathways by human tumour viruses. Viruses, 2015; 7: 25422591

[77] Ciccia A., Elledge S.J.: The DNA damage response: Making it safe to play with knives. Mol. Cell, 2010; 40: 179-204

[78] Nilsson K., Wu C., Schwartz S.: Role of the DNA damage response in human papillomavirus RNA splicing and polyadenylation. Int. J. Mol. Sci., 2018; 19: 1735

[79] Kee Y., D'Andrea A.D.: Expanded roles of the Fanconi anemia pathway in preserving genomic stability. Genes Dev., 2010; 24: 1680-1694

[80] Moody C.A., Laimins L.A.: Human papillomaviruses activate the ATM DNA damage pathway for viral genome amplification upon differentiation. PLoS Pathog., 2009; 5: e1000605

[81] Sakakibara N., Mitra R., McBride A.A.: The papillomavirus E1 helicase activates a cellular DNA damage response in viral replication foci. J. Virol., 2011; 85: 8981-8995

[82] Gillespie K.A., Mehta K.P., Laimins L.A., Moody C.A.: Human papillomaviruses recruit cellular DNA repair and homologous recombination factors to viral replication centers. J. Virol., 2012; 86: 9520-9526
[83] McKinney C.C., Hussmann K.L., McBride A.A.: The role of the DNA damage response throughout the papillomavirus life cycle. Viruses, 2015; 7: 2450-2469

[84] Anacker D.C., Gautam D., Gillespie K.A., Chappell W.H., Moody C.A.: Productive replication of human papillomavirus 31 requires DNA repair factor Nbs1. J. Virol., 2014; 88: 8528-8544

[85] Chappell W.H., Gautam D., Ok S.T., Johnson B.A., Anacker D.C., Moody C.A.: Homologous recombination repair factors Rad51 and BRCA1 are necessary for productive replication of human papillomavirus 31. J. Virol., 2015; 90: 2639-2652

[86] Hong S., Dutta A., Laimins L.A.: The acetyltransferase Tip60 is a critical regulator of the differentiation-dependent amplification of human papillomaviruses. J. Virol., 2015; 89: 4668-4675

[87] Langsfeld E.S., Bodily J.M., Laimins L.A.: The deacetylase sirtuin 1 regulates human papillomavirus replication by modulating histone acetylation and recruitment of DNA damage factors NBS1 and Rad51 to viral genomes. PLoS Pathog, 2015; 11: e1005181

[88] Hoffmann R., Hirt B., Bechtold V., Beard P., Raj K.: Different modes of human papillomavirus DNA replication during maintenance. J. Virol., 2006; 80: 4431-4439

[89] Mehta K., Gunasekharan V., Satsuka A., Laimins L.A.: Human papillomaviruses activate and recruit SMC1 cohesin proteins for the differentiation-dependent life cycle through association with CTCF insulators. PLoS Pathog, 2015; 11: e1004763

[90] Sun M., Nishino T., Marko J.F.: The SMC1-SMC3 cohesin heterodimer structures DNA through supercoiling-dependent loop formation. Nucleic Acids Res., 2013; 41: 6149-6160

[91] Hong S., Cheng S., lovane A., Laimins L.A.: STAT-5 regulates transcription of the topoisomerase $\| \beta$-binding protein 1 (TopBP1) gene to activate the ATR pathway and promote human papillomavirus replication. mBio, 2015; 6: e02006-15

[92] Reinson T., Toots M., Kadaja M., Pipitch R., Allik M., Ustav E., Ustav M.: Engagement of the ATR-dependent DNA damage response at the human papillomavirus 18 replication centers during the initial amplification. J. Virol., 2013; 87: 951-964

[93] Bristol M.L., Das D., Morgan I.M.: Why human papillomaviruses activate the DNA damage response (DDR) and how cellular and viral replication persists in the presence of DDR signaling. Viruses, 2017; 9: 268

[94] Anacker D.C., Moody C.A.: Modulation of the DNA damage response during the life cycle of human papillomaviruses. Virus Res., 2017; 231: 41-49

[95] Anacker D.C., Aloor H.L., Shepard C.N., Lenzi G.M., Johnson B.A., Kim B., Moody C.A.: HPV31 utilizes the ATR-Chk1 pathway to maintain elevated RRM2 levels and a replication-competent environment in differentiating keratinocytes. Virology, 2016; 499: 383-396

[96] Edwards T.G., Helmus M.J., Koeller K., Bashkin J.K., Fisher C.: Human papillomavirus episome stability is reduced by aphidicolin and controlled by DNA damage response pathways. J. Virol., 2013; 87: 3979-3989 
[97] Moody C.A.: Impact of replication stress in human papillomavirus pathogenesis. J. Virol., 2019; 93: e01012-17

[98] Bester A.C., Roniger M., Oren Y.S., Im M.M., Sarni D., Chaoat M., Bensimon A., Zamir G., Shewach D.S., Kerem B.: Nucleotide deficiency promotes genomic instability in early stages of cancer development. Cell, 2011; 145: 435-446

[99] Kotsantis P., Petermann E., Boulton S.J.: Mechanisms of oncogene-induced replication stress: Jigsaw falling into place. Cancer Discov., 2018; 8: 537-555

[100] Bertoli C., Herlihy A.E., Pennycook B.R., Kriston-Vizi J., de Bruin R.A.: Sustained E2F-dependent transcription is a key mechanism to prevent replication-stress-induced DNA damage. Cell Rep., 2016; 15: 1412-1422

[101] Herlihy A.E., de Bruin R.A.: The role of the transcriptional response to DNA replication stress. Genes, 2017; 8: 92

[102] Toledo L.I., Murga M., Zur R., Soria R., Rodriguez A., Martinez S., Oyarzabal J., Pastor J., Bischoff J.R., Fernandez-Capetillo O.: A cell-based screen identifies ATR inhibitors with synthetic lethal properties for cancer-associated mutations. Nat. Struct. Mol. Biol., 2011; 18: 721-727

[103] Jang M.K., Shen K., McBride A.A.: Papillomavirus genomes associate with BRD4 to replicate at fragile sites in the host genome. PLoS Pathog, 2014; 10: e1004117

[104] Sarni D., Kerem B.: The complex nature of fragile site plasticity and its importance in cancer. Curr. Opin. Cell Biol., 2016; 40: 131-136

[105] Mehta K., Laimins L.: Human papillomaviruses preferentially recruit DNA repair factors to viral genomes for rapid repair and amplification. mBio, 2018; 9: e00064-18

[106] Bodelon C., Untereiner M.E., Machiela M.J., Vinokurova S., Wentzensen N.: Genomic characterization of viral integration sites in HPV-related cancers. Int. J. Cancer, 2016; 139: 2001-2011

[107] McBride A.A.: Playing with fire: Consequences of human papillomavirus DNA replication adjacent to genetically unstable regions of host chromatin. Curr. Opin. Virol., 2017; 26: 63-68

[108] Wallace N.A., Khanal S., Robinson K.L., Wendel S.O., Messer J.J., Galloway D.A.: High-risk Alphapapillomavirus oncogenes impair the homologous recombination pathway. J. Virol., 2017; 91 : e01084-17

[109] Gao G., Johnson S.H., Vasmatzis G., Pauley C.E., Tombers N.M., Kasperbauer J.L., Smith D.I.: Common fragile sites (CFS) and extremely large CFS genes are targets for human papillomavirus integrations and chromosome rearrangements in oropharyngeal squamous cell carcinoma. Genes Chromosomes Cancer, 2017; 56: 59-74

[110] McBride A.A., Warburton A.: The role of integration in oncogenic progression of HPV-associated cancers. PLOS Pathog., 2017; 13 : e1006211

[111] Liu G.B., Chen J., Wu Z.H., Zhao K.N.: Association of human papillomavirus with Fanconi anemia promotes carcinogenesis in Fanconi anemia patients. Rev. Med. Virol., 2015; 25: 345-353

[112] Hoskins E.E., Gunawardena R.W., Habash K.B., Wise-Draper T.M., Jansen M., Knudsen E.S., Wells S.I.: Coordinate regulation of Fanconi anemia gene expression occurs through the Rb/E2F pathway. Oncogene, 2008; 27: 4798-4808

[113] Spardy N., Duensing A., Hoskins E.E., Wells S.I., Duensing S.: HPV-16 E7 reveals a link between DNA replication stress, Fanconi anemia D2 protein, and alternative lengthening of telomereassociated promyelocytic leukemia bodies. Cancer Res., 2008; 68: 9954-9963

[114] Hoskins E.E., Morreale R.J., Werner S.P., Higginbotham J.M., Laimins L.A., Lambert P.F., Brown D.R., Gillison M.L., Nuovo G.J., Witte D.P. i wsp.: The Fanconi anemia pathway limits human papilIomavirus replication. J. Virol., 2012; 86: 8131-8138

[115] Park J.W., Pitot H.C., Strati K., Spardy N., Duensing S., Grompe M., Lambert P.F.: Deficiencies in the Fanconi anemia DNA damage response pathway increase sensitivity to HPV-associated head and neck cancer. Cancer Res., 2010; 70: 9959-9968

[116] Spriggs C.C., Laimins L.A.: FANCD2 binds human papillomavirus genomes and associates with a distinct set of DNA repair proteins to regulate viral replication. mBio, 2017; 8: e02340-16

[117] Tan W., van Twest S., Murphy V.J., Deans A.J.: ATR-mediated FANCI phosphorylation regulates both ubiquitination and deubiquitination of FANCD2. Front. Cell Dev. Biol., 2020; 8: 2

[118] Romick-Rosendale L.E., Hoskins E.E., Privette Vinnedge L.M., Foglesong G.D., Brusadelli M.G., Potter S.S., Komurov K., Brugmann S.A., Lambert P.F., Kimple R.J. i wsp.: Defects in the Fanconi anemia pathway in head and neck cancer cells stimulate tumor cell invasion through DNA-PK and Rac1 signaling. Clin. Cancer Res., 2016; 22: 2062-2073 